Environment, Biodiversity \& Soil Security
(EBSS)

\title{
Sustainable Approaches of Trichoderma under Changing Environments for Vegetable Production
}

\author{
Naglaa Taha ${ }^{1}$, Said Kamel ${ }^{1}$, Tamer Elsakhawy ${ }^{2}$, Alaa El-Dein Omara ${ }^{2 *}$, Yousry \\ Bayoumi $^{3,4}$, and Hassan El-Ramady ${ }^{5}$ \\ ${ }^{1}$ Plant Pathology Research Institute, Agriculture Research Center, Sakha, Kafr El- \\ Sheikh, Egypt \\ ${ }^{2}$ Agriculture Microbiology Department, Soil, Water and Environment Research \\ Institute (SWERI), Sakha Agricultural Research Station, Agriculture Research \\ Center (ARC), Kafr El-Sheikh 33717, Egypt \\ ${ }^{3}$ Horticulture Dept., Faculty of Agriculture, Kafrelsheikh University, Egypt \\ ${ }^{4}$ Physiology \& Breeding of Horticultural Crops Laboratory, Horticulture \\ Dept.,Faculty of Agriculture, Kafrelsheikh University, Egypt \\ ${ }^{5}$ Soil and Water Dept., Faculty of Agriculture, Kafrelsheikh University, Egypt
}

\begin{abstract}
$\mathbf{T}$ HE world's burgeoning population faces a great challenge concerning food security, which could be achieved through different sustainable agricultural practices. Trichoderma, as a ubiquitous fungus, is one of the most promising microorganisms that might offer several avenues for sustainable agriculture. Trichoderma spp. may guarantee a better solution for conventional problems in agriculture through several approaches including the protection of cultivated plants from undesirable abiotic and biotic conditions under changing environments and promoting their growth in poor or limited soil nutrients. The promising role of Trichoderma for vegetable production as a biocontrol and biofertilizers has been confirmed but its role as a plant pathogen still needs more studies. Trichoderma could inhibit or suppress the growth of soil phytopathogens, promoting plant growth and soil health, through activation of many mechanisms including synthesis of antibiotics, mycoparasitism and competition for nutrients and space against plant deleterious microorganisms. The sustainable approaches of Trichoderma including biofortification, bio-remediation and phyto-remediationas well as exploring future research opportunities will be also addressed in this work.
\end{abstract}

Keywords: Abiotic stress, Climate changes, Drought, Salinity, Heat stress.

\section{Introduction}

Plants, microorganisms and animals are the common living organisms in terrestrial eco systems, which engage in multiple interactions. These interactions could be classified on their effects on plant's developmentinto neutral, beneficial and deleterious groups (Kare et al. 2020). These interactions also may include both detrimental and beneficial at multiple trophic levels (Kredics et al. 2018). Cultivated plants face a lot of aggressors including pathogenic microorganisms and herbivorous arthropods, which activate plant corresponding signaling defense mechanisms (Macías-Rodríguez et al. 2020). Under certain circumstances, however, these plants are beinga target for multiple aggressors, thensome pathways could have profound effects on plant defense and resistance to attack (Macías-Rodríguez et al. 2020). The rhizospheric microorganisms may support the cultivated plants in enabling plants

Corresponding author : E-mail: alaa.omara@yahoo.com

Authors' E-mails: nagla abdelbaset@yahoo.com; said kamel88@yahoo.com

drelsakhawyg@gmail.com; ybayoumi2002@yahoo.com.sg; hassan.elramady@agr.kfs.edu.eg

Received: 4/10/2020; Accepted: 8/11/2020

DOI: $10.21608 /$ jenvbs.2020.45046.1109

C2020 National Information and Documentation Center (NIDOC) 
cope with different environmental stresses or in counteracting plant invaders (Solanki et al. 2021). Plant beneficial rhizospheric microorganisms have the ability to promotesoil health and its quality, the growth of cultivated plants and its development, improveplant nutrient use efficiency, the decomposition of soil organic matter and increase the availability and cycling of nutrients (Meena et al. 2017; Alami et al. 2020). The common rhizospheric microorganisms include bacteria, fungi, actinomycetes, and algae, whereas the Trichoderma is considered one of the most important genera of fungi.

Trichoderma, as a genus of fungi belongs the family of Hypocreaceae, is common in all different soils and presents the most prevalent culturable fungi. Several species in this Trichoderma genus (e.g., T. asperellum, T. hamatum, T. harzianum, T. koningii) could be characterized as excellent biocontrol agents (biofungicides) enhance plant resistance, biofertilizers promote plant growth and improve soil quality (Saravanakumar and Wang, 2020). Persoon successed to isolate Trichoderma in 1794 for the first time from decomposing organic matter and soil (Sood et al. 2020). Trichoderma spp. are considered rhizosphere inhabitants, universal saprotrophic fungi that dominant in the terrestrial ecosystems and they mediate interactions amongplants, other soil microorganisms and arthropods at multiple trophic levels (Macías-Rodríguez et al. 2020). Trichoderma spp. also have multiple beneficial attributes, whichsupport their applications as an appropriate tool for establishing the sustainability of agricultural practices (Sachdev and Singh, 2020). The maximum growth of Trichoderma species could be achieved when grown at $25-30^{\circ}$, whereas some species can grow well and sporulates at $35^{\circ}$. Trichoderma species usually have hyaline, septated and smooth-walled vegetative hyphaeas well as highly branched conidiophores could be found (Gorai et al. 2020).

Agriculture sector is the main source that provides the human with the essential foods including the cultivated fruits, vegetables and spices as well as other food plants, which supplement the healthy human diet with essential micronutrients and other nutritional components. Vegetable crops comprise a wide range of genera and species, whichconsider an important component of the healthy human diet through supply the human with minerals, amino acids, antioxidants, vitamins, fiber and

Env. Biodiv. Soil Security Vol. 4 (2020) other health-promoting compounds (Ebert, 2020). The global vegetables, also called the most dominant vegetables, are grown plants in several countries worldwide including cucurbits (squashes, cucumbers, pumpkins and gherkins), tomatoes, spinach, alliums (garlic, onion and shallot), chilies (sweet and hot pepper), brassicas (broccoli, cabbages and rape), eggplants, vegetable legumes, lettuce, turnips, carrots and asparagus (Ebert, 2020). The production of vegetables under supplying with Trichoderma may support the production of these vegetables and their resistance to different vegetable pathogens (Rivera-Méndez, 2020).

Therefore, this review is an attempt to provide insight on the functioning of Trichoderma under different environmental conditions to increase understanding for their effective use in maintaining the sustainability of different agricultural systems.

\section{Trichoderma: General Features}

Trichoderma is considered the largest taxon among the fungicolous fungal genera with many ubiquitously distributed species (Kubicek et al. 2019). Trichoderma is a ubiquitous genus, belongs to the Ascomyceta division, filamentous saprophytic fungus and is opportunistic plant symbionts, which commonly colonize soils rich in organic matter (Macías-Rodríguez et al. 2020). These fungi typically inhabit several soils including clay and sand and in tropical soils (Bononi et al. 2020). This fungus also could proliferate freely in soils and/or shows symbiotic relation with the roots of cultivated plants and foliar parts (Sachdev and Singh, 2020). The density population of Trichoderma have been estimated in the rhizosphere in a range between $10-1000$ CFU g ${ }^{-1}$ (Cordier et al. 2007). Some Trichoderma strains could colonize the plant roots that cultured in both acidic and alkaline soils and can also subsist in soils containing high levels of cobalt and nickel (Zhang et al. 2018).

More than 254 species of Trichoderma have been formerly identified and also more than 71 species of Trichoderma between 2015 and 2018 were newly identified (Qiao et al.2018) as well as a lot of species undoubtedly are awaiting discovery in the future. It is reported that Trichoderma has a wide geographical distribution under different climatic zones ranging from tropical climate to polar and could sustain its life under different climatic conditions (Sachdev and Singh, 2020). More than 479 volatile organic compounds 
have been identified, which are produced by Trichoderma (e.g., alkanes, alcohols, furans, ketones and pyrones). These compounds are strain-specific, which their production depends on the components of the growth media on which they are grown (González-Pérez et al. 2018; Macías-Rodríguez et al. 2020). The most versatile species of the genus Trichoderma may include the following :

T. afroharzianum, T. arundinaceum, $T$. asperellum, T. atroviride, T. citrinoviride, $T$. cremeum, T. crissum, T. guizouense, T. gamsii, T. harzianum, T. hamatum, T. koningiopsis, $T$. koningii, T. longipile, T. longibrachiatum, $T$. parareesei, T. pseudokoningii, T. polysporum, T. ovalisporum, T. reesei, $T$. saturnisporum, $T$. spirale, T. virens and T. viride (Kubicek et al. 2019; Gautam and Naraian, 2020).

Trichoderma spp. are versatile fungi having multiple beneficial attributes, which make them a promising tool for establishing agricultural sustainability. These attributions may include the potential of Trichodermaspp. as biocontrol agents or biological control (Sachdev and Singh 2018), plant growth promoter (Sachdev et al. 2018) and as plant-growth-promoting fungior biofertilizers (Sachdev and Singh, 2020). Trichoderma spp. also have a distinguished role in physiological stress mitigation and the bioremediation of polluted soils (Tripathi et al. 2017; Sachdev and Singh, 2020). Several species of Trichoderma could reduce the abundance of many microbial phytopathogensin rhizosphere through potent inhibitory molecules (e.g., siderophores and gliovirin). Trichoderma also could enhance plant growth and then crop productivity through alleviating of the abiotic stress (Macías-Rodríguez et al. 2020). Such beneficial effects of Trichoderma may be mediated by the activation of endogenous mechanisms controlled by phytohormones (e.g., abscisic acid and auxins) andvia the alterations in metabolism of the host plants (Fig. 1). Under stress, Trichoderma couldmediate early defense responses and stimulate plant immunity by enhancing plant resistance, which regulated by the phytohormones (e.g., ethylene, salicylic and jasmonic acid). Several volatile organic compounds and oxygen or nitrogen heterocyclic compounds also could bereleased by Trichoderma, which serve as signaling molecules, that effect on plant growth, herbivorous insects and phytopathogen levels (Macías-Rodríguez et al. 2020).

\section{Trichoderma as Biocontrol}

Biocontrol or biological control means the reducing or controlling of diseases or pestsusing one or more useful micro-organisms, which have no impacts on the environment and other helpful micro-organisms such as some fungi and bacteria (Gorai et al. 2020). Trichoderma as important fungi have many potential biocontrol techniques in different agricultural fields, i.e., they antagonize a wide range of phyto-pathogenic fungi (Fig. 2 - 5). Recently, Trichoderma was involved in several commercial products to improve soils, as soil improvements, biopesticides and enhancers for plant growth (Gorai et al. 2020). It is reported that disease incidence by different phytopathogens could be listed as follows: virus (47\%), fungus $(30 \%)$, bacterium $(16 \%)$, phytoplasma $(4 \%)$, and nematode (1\%) (Tripathi et al. 2020). The background and historical side of biological control in genomic era were listed by Tripathi et al. (2020) as follows :

\footnotetext{
1986 Demonstration of plant growth promotion by Trichoderma

1987 Successful transformation of T. reesei

1992 Lectin-coated model for Trichoderma/biomimitics

1999 Demonstration of internal colonization of plant roots by Trichoderma

2003 MAPK negatively regulate conidiation in $T$. virens

2005 Role of Trichoderma MAPK in ISR

2008 First Trichoderma genomes sequenced and published (T. reesei)

2009 Endophytism, Trichoderma imparts biotic and abiotic stress tolerance

2009 First time successful crossing in T. reesei under laboratory condition

2010 Pheromone precursor genes described in Trichoderma comparative genome analysis using NGS of different Trichoderma species
}

2012 Knock out program in Trichoderma 


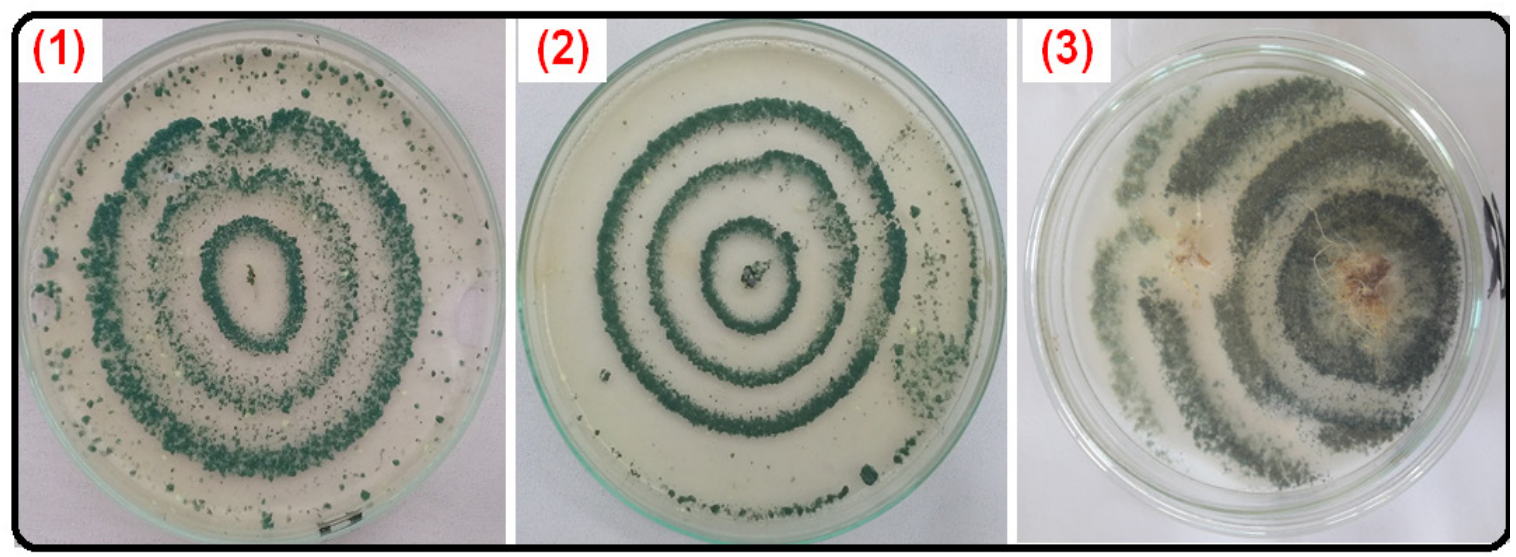

Fig. 1. Trichoderma in nature, photos 1 and 2 represent isolated T. harzianum from the soil of Kafr El-Sheikh, Egypt and the photo 3 for T. harzianum, which was isolated from the roots of tomato infested by Fusarium wilt

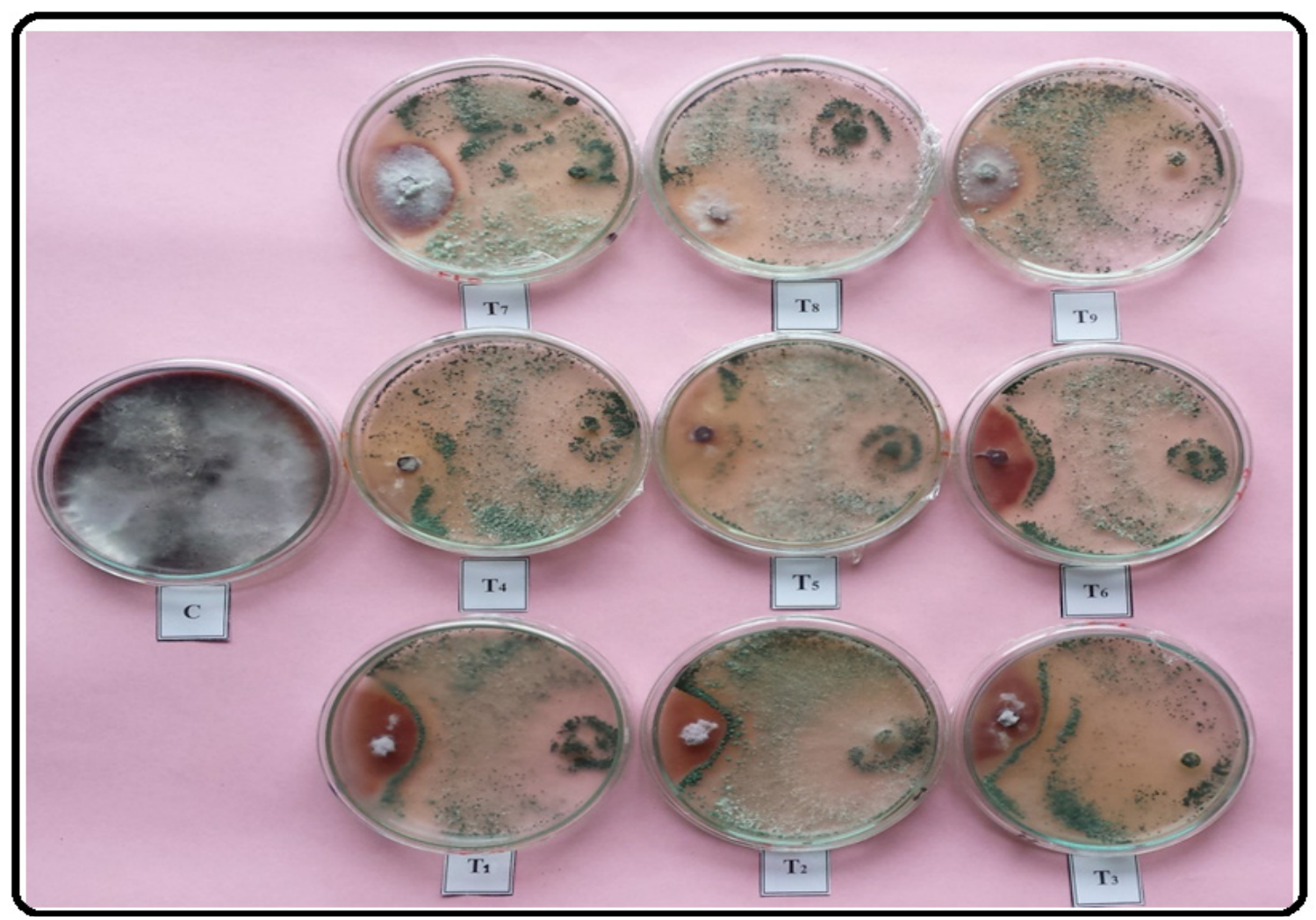

Fig. 2. The antagonism of Trichoderma spp. against $F$. oxysporum f. sp. cucumerinum, the casual pathogen of fusarium wilt of cucumber

The mechanisms of biological control are considered significant measures for disease management because chemical fungicides compared to Trichoderma adversely impact on other non-target organisms (El Enshasy et al. 2020). Trichoderma could cause growth inhibition of different species of phyto-pathogens by establishing a parasitic relationship and/or impairing their metabolisms. The application of biocontrol agents could stimulate disease suppression under a high doses of chemical fungicide treatments, where about $90 \%$ of strains of Trichoderma represent fungal biocontrol agents against pathogenic microorganisms (Sood et al. 2020).

Env. Biodiv. Soil Security Vol. 4 (2020) 


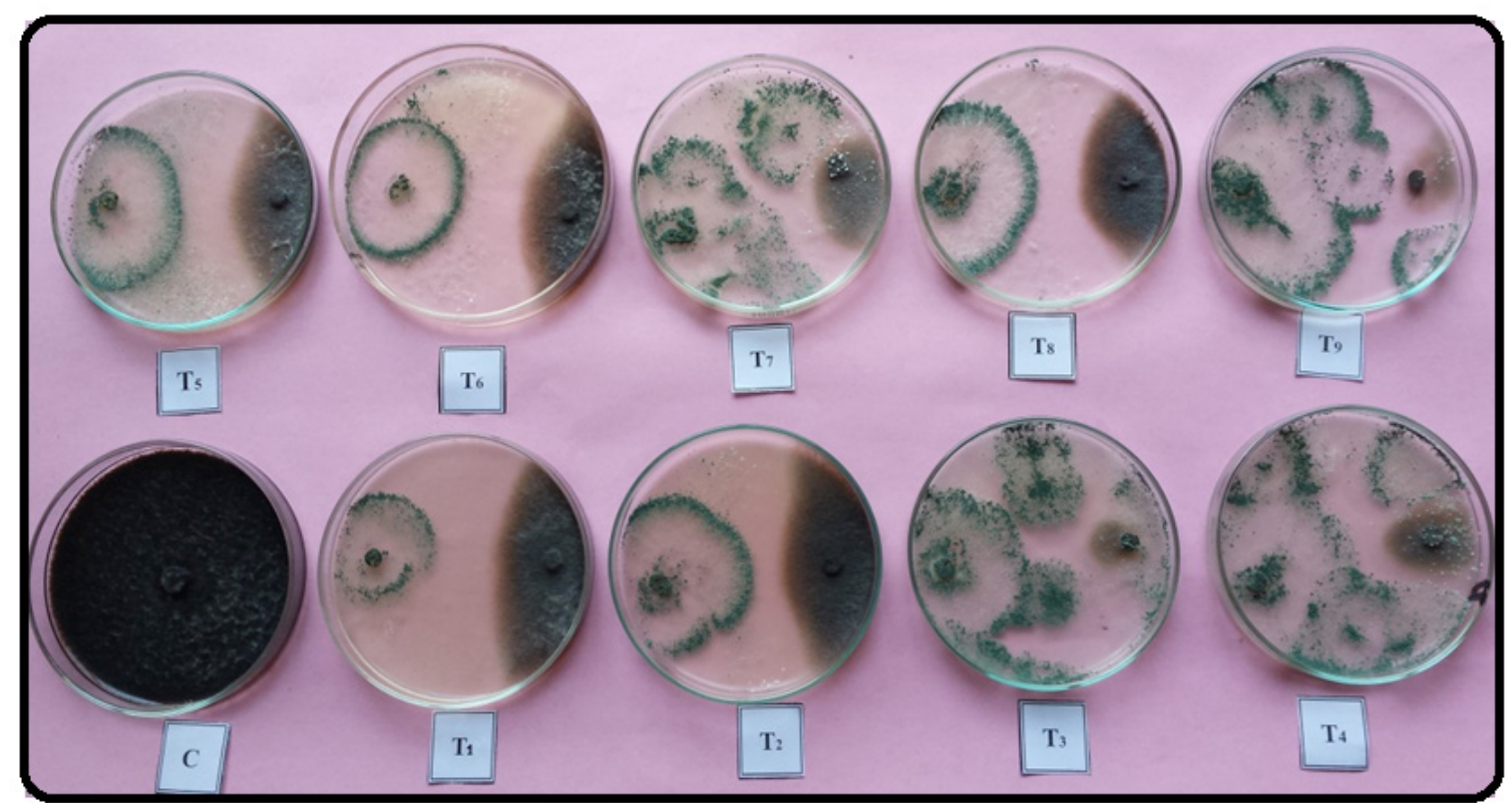

Fig. 3. Two case studies for Trichoderma as biocontrol against charcoal rot in Macrophomina phaseoli

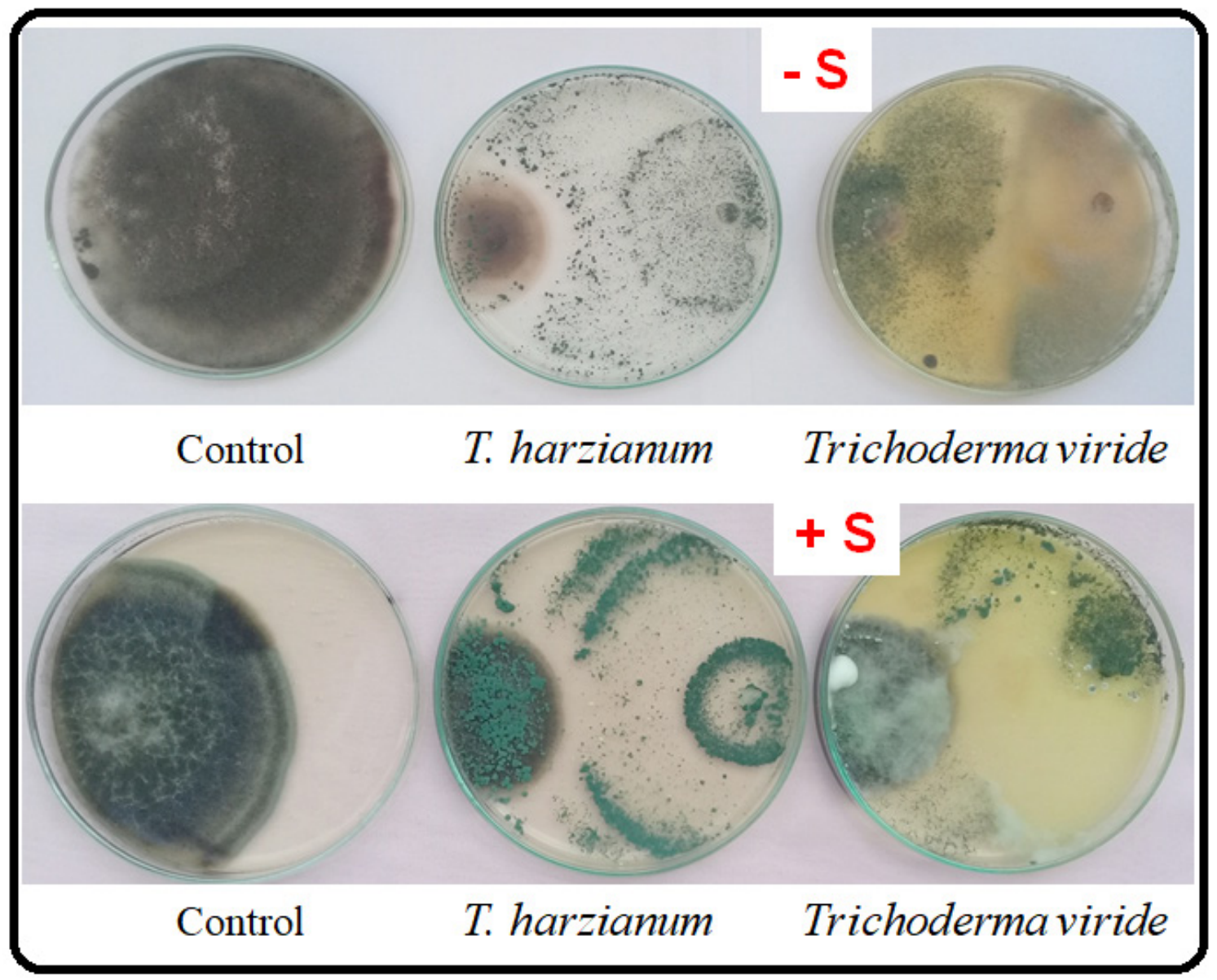

Fig. 4. The highest antagonistic effect of both T. harzianum and T. viride against Alternaria porri in onion in presense or absent ( $\mathrm{S}$ at $2 \mathrm{~g} \mathrm{l}^{-1}$ ) (Bayoumi et al. 2019) 


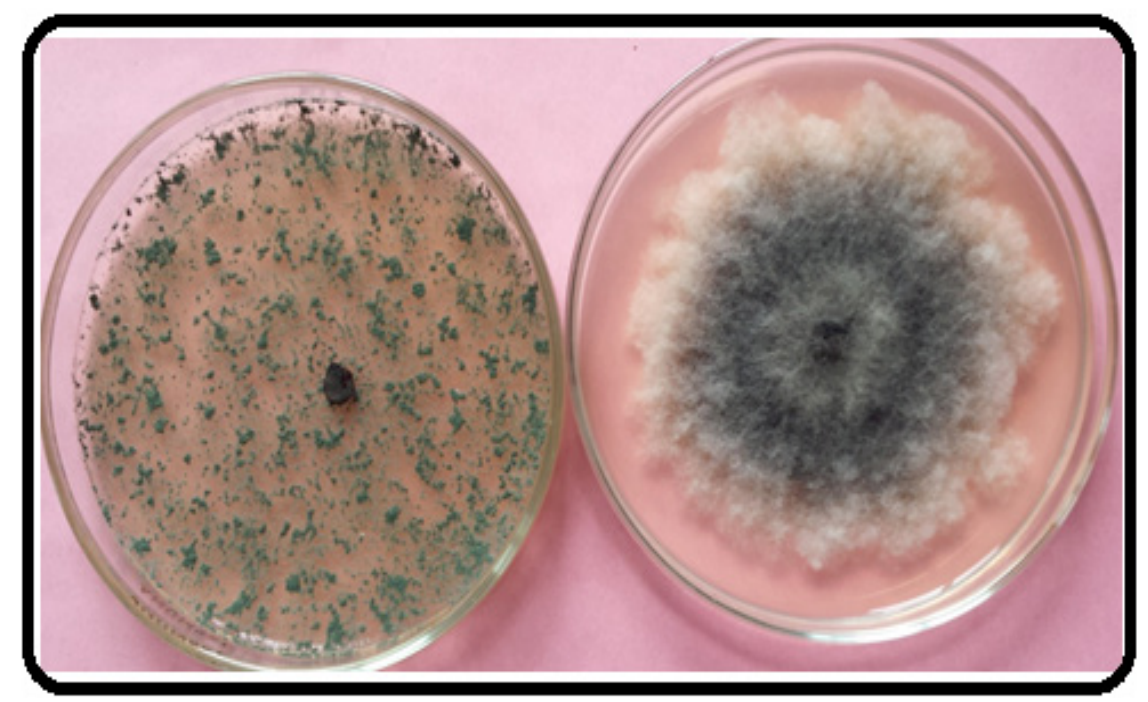

Fig. 5. The antagonism of Trichoderma asperellium against charcoal rotin M. phaseoli, where the Trichoderma inhibited the activity of the phytopathogen of M. phaseoli by $100 \%$.

The mechanisms of biological control are considered significant measures for disease management because chemical fungicides compared to Trichoderma adversely impact on other non-target organisms (El Enshasy et al. 2020). T. richoderma could cause growth inhibition of different species of phyto-pathogens by establishing a parasitic relationship and/or impairing their metabolisms. The application of biocontrol agents could stimulate disease suppression under a high doses of chemical fungicide treatments, where about $90 \%$ of strains of Trichoderma represent fungal biocontrol agents against pathogenic microorganisms (Sood et al. 2020).

It is confirmed by several researchers that Trichoderma spp. are considered promising biocontrol agents against a lot of phytopathogensthat attack vegetable crops like tomato (Table 1; e.g., Salas-Marina et al. 2011; Brotman et al. 2012; Suárez-Estrella et al. 2014; de Medeiros et al. 2017; Jogaiah et al. 2018; Herrera-Téllez et al. 2019; Chien and Huang 2020; Kashyap et al. 2020; Morán-Diez et al. 2020). Trichoderma spp. can also enhance both direct and indirect defense barriers against aphids ( $T$. harzianum) and insects (T.atroviride) as reported by Coppola et al. (2019 a, b). Concerning the mode of action of Trichoderma spp.in destroying pathogenic fungi, Trichoderma could release thelytic enzymes in the rhizosphere. These enzymes might catalyze the cell wall damage to target fungi, then, asignaling cascade is activated in Trichoderma cells. This signaling may involve the activation of mitogen-activatedprotein kinase through proteincoupled receptors, then programmed cell death may establish due to changes in gene expression ultimately in pathogenic fungi (Sood et al. 2020). List of plant pathogens that can becontrolled by Trichoderma spp. in some vegetable crops including tomato, onion, cucumber and potato is listed in Table 2.

It is worth mention that "Could Trichoderma Be a Plant Pathogen? Successful Root Colonization" and this question was asked by Poveda et al. (2020). They mentioned that the root colonization by Trichoderma may have two pathways; the first one supposed that the plant defends itself against being colonized by Trichoderma with preventing Trichoderma from penetration the plant vascular bundle and causing the expected indirect benefits, which include increase plant tolerance against abiotic stresses and resistance against pathogens and/ orpests, promote plant growth through improving nutrient acquisition through the roots. The second pathway represents the absence of salicylic acid mediated response, which Trichoderma massively colonizes plant roots, penetrating the vascular bundles, producing plant death and may be becoming an opportunistic pathogen (Poveda et al. 2020). The management of infected plants by Trichoderma has been investigated by many researchers such as Al-Ani and Mohammed (2020), and Kumari et al. (2020). 
TABLE 1. Different Trichoderma strains already used against different pathogens for tomato crop

\begin{tabular}{|c|c|c|c|}
\hline Trichodermastrain & Pathogen & Activity or mechanisms & Reference \\
\hline $\begin{array}{l}\text { Trichoderma } \\
\text { asperellum }\end{array}$ & $\begin{array}{l}\text { Xanthomonas } \\
\text { perforans }\end{array}$ & $\begin{array}{l}\text { Managebacterial spot using Bacillus } \\
\text { amyloliquefaciens }\end{array}$ & $\begin{array}{l}\text { Chienand Huang } \\
\text { (2020) }\end{array}$ \\
\hline $\begin{array}{l}\text { Trichoderma } \\
\text { asperellumand } \\
\text { Trichoderma virens }\end{array}$ & $\begin{array}{l}\text { Root-knot nematode } \\
\text { (Meloidogyne } \\
\text { javanica) }\end{array}$ & $\begin{array}{l}\text { Trichoderma spp. enhance plant growth } \\
\text { in enriched with of water-extractable } \\
\text { fraction of vermicompost }\end{array}$ & $\begin{array}{c}\text { dos Santos Pereira } \\
\text { 2020))et al. }\end{array}$ \\
\hline $\begin{array}{l}\text { T. longibrachiatum } \\
\text { UNS11 }\end{array}$ & $\begin{array}{l}\text { Bacterial wilt } \\
\text { (Ralstonia } \\
\text { solanacearum) }\end{array}$ & $\begin{array}{l}\text { Combined application of Rhizobacteria } \\
\text { and Trichoderma } \\
\text { strains elicite resistance against } \\
\text { bacterial wilt }\end{array}$ & $\begin{array}{l}\text { Konappa et al. } \\
\qquad(2020)\end{array}$ \\
\hline Trichoderma asperellum & $\begin{array}{l}\text { Rhizoctonia } \\
\text { solaniAG-4 }\end{array}$ & $\begin{array}{l}\text { Manage tomato root rot pathogen by } \\
\text { increasing total phenol, polyphenol } \\
\text { oxidase, peroxidase, proline; reducing } \\
\text { sugar, total soluble sugars }\end{array}$ & $\begin{array}{l}\text { Kashyap et al. } \\
\qquad(2020)\end{array}$ \\
\hline $\begin{array}{l}\text { Trichodermaparareesei,T. } \\
\text { asperellum, T. harzianum }\end{array}$ & $\begin{array}{l}\text { Pseudomonas } \\
\text { syringaepv. Tomato, } \\
\text { DC3000, }\end{array}$ & $\begin{array}{l}\text { Phytohormones (e.g., SA, JA, ET } \\
\text { and ABA) maysupportTrichoderma- } \\
\text { induced defenses priming against } \\
\text { pathogen }\end{array}$ & $\begin{array}{l}\text { Morán-Diez et } \\
\text { al. (2020) }\end{array}$ \\
\hline $\begin{array}{l}\text { Trichoderma } \\
\text { asperelloides }\end{array}$ & $\begin{array}{l}\text { Fusarium oxysporum } \\
\text { and } \\
\text { Alternariaalternata }\end{array}$ & $\begin{array}{l}\text { Reducingthe plant disease severity } \\
\text { morethan } 53.8 \text { and } 66.7 \% \text { for each } \\
\text { pathogen, res. }\end{array}$ & $\begin{array}{l}\text { Ramírez-Cariño } \\
\text { et al. (2020) }\end{array}$ \\
\hline Trichoderma harzianum & $\begin{array}{l}\text { Root-knot nematode } \\
\text { (Meloidogyne } \\
\text { javanica) }\end{array}$ & $\begin{array}{l}\text { The combined application of } T \text {. } \\
\text { harzianum, Glomus mosseae, and } \\
\text { Bacillus subtilis promotedthe growth } \\
\text { of tomato }\end{array}$ & $\begin{array}{l}\text { Sohrabi et al. } \\
\qquad(2020)\end{array}$ \\
\hline Trichoderma asperellum & Alternaria alternata & $\begin{array}{l}\text { Enhancing the resistance of seedlings } \\
\text { against pathogen by promoting signal } \\
\text { of hormone transduction genes }\end{array}$ & Yu et al. (2020) \\
\hline Trichoderma asperellum & $\begin{array}{l}\text { Fusarium } \\
\text { oxysporumandBotrytis } \\
\text { cinerea }\end{array}$ & $\begin{array}{l}\text { By inhibition ofROS } \\
\text { productioninduced by pathogen }\end{array}$ & $\begin{array}{l}\text { Herrera-Téllez et } \\
\text { al. (2019) }\end{array}$ \\
\hline $\begin{array}{l}\text { Trichoderma } \\
\text { virens }\end{array}$ & $\begin{array}{l}\text { Fusarium oxysporum } \\
\text { f. sp. lycopersici }\end{array}$ & $\begin{array}{l}\text { Mediating the resistanceagainst } \\
\text { Fusarium wilt by involving the } \\
\text { salicylic and jasmonic acid pathways }\end{array}$ & $\begin{array}{l}\text { Jogaiah et al. } \\
\qquad(2018)\end{array}$ \\
\hline Trichoderma atroviride & $\begin{array}{l}\text { Root-knot nematode } \\
\text { (Meloidogyne } \\
\text { javanica) }\end{array}$ & $\begin{array}{l}\text { Trichoderma promote the production } \\
\text { of auxin to inhibitROS as a major } \\
\text { defensestrategy during plant growth }\end{array}$ & $\begin{array}{l}\text { de Medeiros et } \\
\text { al. (2017) }\end{array}$ \\
\hline Trichoderma harzianum & $\begin{array}{l}\text { Fusarium oxysporum } \\
\text { f. sp. lycopersici }\end{array}$ & $\begin{array}{l}\text { Enhancing the induction of antioxidant } \\
\text { defensesystem against Fusarium in } \\
\text { tomato }\end{array}$ & $\begin{array}{l}\text { Zehra et al. } \\
\qquad(2017)\end{array}$ \\
\hline
\end{tabular}

Abbreviations: Reactive oxygen species (ROS), salicylic acid (SA), jasmonic acid (JA), ethylene (ET), Abscisic acid (ABA), 
TABLE 2. List of plant pathogens controlled by Trichoderma spp. in some vegetable crops

\begin{tabular}{|c|c|c|}
\hline References & Plant pathogens & Trichoderma strain \\
\hline & I. Tomato (Solanum lycopersicum L.) & \\
\hline Bader et al. (2020) & Wilt disease (Fusarium oxysporum) & Trichoderma harzianum \\
\hline Cucu et al. (2020) & $\begin{array}{l}\text { Fusarium wilt, caused by Fusarium oxysporum } \mathrm{f} \text {. } \\
\text { sp. lycopersici }\end{array}$ & Trichoderma sp.TW2 \\
\hline Singh et al. (2020) & Fusarium oxysporum f. sp. lycopersici & Trichoderma asperellum \\
\hline Yu et al. (2020) & $\begin{array}{l}\text { Leafspot disease } \\
\text { (Alternaria alternata) }\end{array}$ & Trichoderma asperellum \\
\hline Sallam et al. (2019) & Wilt disease (F. oxysporum f.sp. lycopersici & $\begin{array}{l}\text { Trichoderma atroviride and } T \text {. } \\
\text { longibrachiatum }\end{array}$ \\
\hline $\begin{array}{l}\text { Elshahawy and El- } \\
\text { Mohamedy (2019) }\end{array}$ & Rootrot (Pythium aphanidermatum) & $\begin{array}{l}\text { Trichoderma harzianum, } T \text {. } \\
\text { asperellum, and } T \text {. virens }\end{array}$ \\
\hline Konappa et al. (2018) & Bacterial wilt caused byRalstonia solanacearum & T. asperellum \\
\hline \multirow[t]{2}{*}{ Li et al. (2018) } & $\begin{array}{l}\text { Fusarium wilt, caused by Fusarium oxysporum } \mathrm{f} \text {. } \\
\text { sp. lycopersici }\end{array}$ & Trichoderma asperellum \\
\hline & II. Onion (Allium cepa L.) & \\
\hline Rivera-Méndez et al. (2020) & White rot (Sclerotium cepivorum) & Trichoderma asperellum \\
\hline $\begin{array}{l}\text { Zapata-Sarmiento et al. } \\
(2020)\end{array}$ & $\begin{array}{l}\text { Leaf blight disease caused by Stemphylium } \\
\text { vesicarium }\end{array}$ & Trichoderma asperellum \\
\hline da Silva et al. (2020) & $\begin{array}{l}\text { White mold or sclerotinia rot or wilt Sclerotinia } \\
\text { sclerotiorum (Lib.) }\end{array}$ & T. lentiforme \\
\hline $\begin{array}{l}\text { Bunbury-Blanchette and } \\
\text { Walker (2019) }\end{array}$ & Fusarium basal rot (F. oxysporum f. sp. cepae) & $\begin{array}{l}\text { Trichoderma hamatum and } T \text {. } \\
\text { harzianum }\end{array}$ \\
\hline Bayoumi et al. (2019) & Purple blotch disease (Alternaria porri) & T. harzianum and T. viride \\
\hline \multirow[t]{2}{*}{ Abdelrahman et al. (2016) } & Fusarium oxysporum f. sp. сера & T. longibrachiatum \\
\hline & III. Cucumber (Cucumis sativus L.) & \\
\hline Zhang and Zhuang (2020) & Pathogenic fungus Rhizoctonia solani & Trichoderma brevicrassum \\
\hline Yuan et al. (2019) & Graymold disease (Botrytis cinereal) & T. longibrachiatum \\
\hline Cong et al. (2019) & Fusarium wilt (F.oxysporumf.sp.cucumerinum) & T. pseudokoningii \\
\hline Li et al. (2019) & Fusarium oxysporum $f$. sp. cucumerinum Owen & $\begin{array}{l}\text { T. asperellum, T. harzianum, } \\
\text { and T. pseudokoningii }\end{array}$ \\
\hline Nawrocka et al. (2019) & Pathogenicfungus Rhizoctonia solani & Trichoderma atroviride TRS 25 \\
\hline \multirow[t]{2}{*}{ Nawrocka et al. (2018) } & Rhizoctonia solani & Trichoderma atroviride \\
\hline & IV. Potato (Solanum tuberosum L.) & \\
\hline Mohamed et al. (2020) & Ralstonia solanacearum & Trichoderma asperellum \\
\hline Elazouni et al. (2019) & Ralstonia solanacearum & T. harzianum and T. viride \\
\hline Wang et al. (2019) & Potato scab (Streptomyces spp.) & Trichoderma harzianum \\
\hline
\end{tabular}




\section{Trichoderma as Biofertilizer}

Cultivated plantsdepend mainly on the nutrient available forms from organic and inorganic sources to satisfy their needs. The mineral sources of nutrients may lead to several environmental problems e.g., groundwater pollution and its negative implications on human health (Kumari and Singh, 2019). Thus, these mineral fertilizers alone do not guarantee sustainable and safe production of food. Theorganic farming is considered a proper way in replacing several agrochemicals by potential microbes and their products towards a sustainable and high crop production. Moreover, the combined application of both organic fertilizers and biofertilizers like Trichoderma are needed to achieve these aims. The efficiency of this approach was comparable with the traditional mineral fertilization one (Zhang et al. 2018). Biofertilizers have themagical ability to support plant growth and its development (Yin et al. 2020). On the other hand, biosafety criteria, based on the European Regulation 2019/1009, are needed for microorganism selection as biofertilizers or bio-stimulants (Barros-Rodríguez et al. 2020). Biofertilizer as a technique has been improved and many new techniques in its processing had been developed as well to enhance its effects on plant system. This bio-approach can be used safely as biocontrol against plant pathogens and also as plant growth promotors (Sahu et al. 2018). The term biofertilizer is defined as a product containing beneficial micro-organisms, which has the potential to improve the fertility of soils and crop productivity as well as an eco-friendly environmental tool (El-Ghamry et al. 2018; Atieno et al. 2020).

Several exudates (e.g., IAA and GA3) could be secreted from the active roots in the rhizosphere attracting many microorganisms, then associate and enhance nutrients availability in the active feeding area of plant roots (Rebolledo-Prudencioa et al. 2020). These all beneficial microbes could be divided into two classes plant health promoters and plant growth promoters (Sahu et al. 2018). Trichoderma spp. are well-known as plant growth-promoting fungi, which could enhance the plant uptake of nutrients, producing plant growth hormones and protecting cultivated plants from pathogen infection (Zhang et al. 2018). Several studied emphasized the role of Trichoderma as a biofertilizer in vegetable crop production such as tomato (Khan et al. 2017; De Palma et al. 2019; Sani et al. 2020), cucumber (Zhang et al. 2019) and cabbage (Liu et al. 2016; Ji et al. 2020).

It could be classified biofertilizers into different types based on the group of microorganisms in biofertilizers and these types may include: (1) nitrogen fixing biofertilizers, (2) phosphorus biofertilizers,(3) plant growth promoting biofertilizers, (4) potassium biofertilizers,(5) zinc solubilizing biofertilizers, (6) sulfur oxidizing biofertilizers, and (7) silicate solubilizing biofertilizers (Mącik et al. 2020). On the other hand, several species of Trichoderma have been used successfully as biofertilizers for many cultivated crops such as :

1. Rice (Oryza sativa L.): T. asperellum SL2 (Doni et al. 2018), T. erinaceum (Swain et al. 2018), T. reesei (Singh et al. 2019),

2. Brassica rapa: T. harzianum (Caporale et al. 2019),

3. Brassica chinensis: T. brevicompactum (Yin et al. 2020),

4. Chinese cabbage:a mixture of T. harzianum, T. asperellum, $T$. hamatum, and $T$. atrovirideon (Ji et al. 2020),

5. Alfalfa (Medicago sativa L.): Trichodermaharzianum (Zhang et al. 2020),

6. Sorghum (Sorghum bicolor L.): Trichodermaviride (Wang et al. 2018),

7. Bean (Phaseolus vulgaris L.): Trichodermaharzianum strains (Eslahi et al. 2020a),

8. Lettuce (Lactuca sativa L.): Trichoderma asperellum (Wonglom et al. 2020),

9. Black pepper (Piper nigrum L.): Trichoderma harzianum (Umadevi et al. 2018), and

10. Maize (Zea mays L.): Trichoderma harzianum T-soybean (Zhang et al. 2020).

\section{Trichoderma under stress}

The genus of Trichoderma as a fungal species is considered the most promising microorganisms that improvesthe growth of cultivated plants by enhancing the uptake of nutrients and supporting them against environmental abiotic and biotic stresses (Khoshmanzar et al. 2020). Trichoderma 
cancolonize the roots of cultivated plants and then produce some secondary metabolites stimulating the growth of plants,improving water use efficiency, and alleviating ROS damage under abiotic and biotic stress conditions by secretion some phytohormones (Khoshmanzar et al. 2020). Several studies have been confirmed that the treated plants with Trichoderma have the ability to increase the tolerance of cultivated plants to abiotic and biotic stresses (Table 3 ).

In this context, Trichoderma could activate the plant systemic resistance against phytopathogens through the induction of the signaling pathways of jasmonic acid and ethylene as well as salicylic acid. Moreover, Trichoderma has the ability to prime plants against subsequent attacks by pathogens. Concerning biotic stress, several plants species showed the increased resistance to pathogen attack when pretreated with Trichoderma like cotton, common bean, tomato, cucumber, pepper, lettuce, maize, and rice (Rebolledo-Prudencioa et al. 2020). Different Trichoderma strains can also induce protective effects against different pathogensas presented in Table 3. For instance, the colonization of maizeroots can effectively reduce the damage caused by many phytopathogens when treated with some Trichoderma spp. (Fig. 6). like T. asperellum GDFS1009 for Fusarium graminearum (Karuppiah et al. 2019), and $T$. harzianum INAT11 for Fusarium verticillioides and Fusarium graminearum (Ferrigo et al. 2020). The ameliorative role of Trichoderma under abiotic stress has been also confirmed by many investigations like treating wheat with Trichoderma longibrachiatum under salinity (10 and $20 \mathrm{~g}^{-1} \mathrm{NaCl}$ ) as published by Zhang et al. (2019). It is reported also that, chlorophyll and water contents in both leaves and roots increased significantly in wheat plants inoculated with $T$. longibrachiatum under salinity stress conditions. Its deference mechanism may take place through stimulating antioxidant activities of the plant defense enzymes i.e., catalase (CAT), peroxidase(POD) and superoxide dismutase (SOD), enzymes compared to wheat-untreated plants (Rebolledo-Prudencioa et al. 2020). Under drought stress, it is common the reduction in plant content of chlorophyll and carotenoids as well as the severe damage in maize membrane; however, this damage can be avoided when maize inoculated with $T$. atroviride ID20G. Also, inoculating rice with Trichoderma spp. Was found effective in improving the growth parameters of plants grown under droughtconditions and sheath blight (Rhizoctonia solani) disease (Mishra et al. 2020).

\section{Trichoderma for Sustainable Agriculture}

Sustainability in agriculture may include building and maintaining the soil health, managing water and its quality, minimizing the pollution in soil, water, and air environments, and promoting soil biodiversity (Thakur 2020). No doubt that sustainable agricultural practices are needed to be the key for food security of the world's burgeoning population and Trichoderma might offer a lot of solutions for sustainable agriculture (Sachdev and Singh, 2020). Trichoderma could also alleviate the abiotic and/or biotic stress as plant symbionts through the colonization of plant roots and establishing a communication with the host plant via chemical signals. These signals may induce the plant resistance against stresses by secreting phytohormones (e.g., salsylic acid and jasmonate) and other secondary metabolites (Malinich et al. 2019). Then, Trichoderma may support the bio-protection against the phytopathogens by release antibiotic compounds, competing for nutrition and space, improve the plant uptake of water and nutrients, and acidify ambient environment. This acidification could be achieved through secretions of many organic acids, which increase the solubility of micronutrients and minerals for biofertilization (Sachdev and Singh 2020). It is reported that Trichoderma is considered the most widespread genus of fungi marketed as bio-pesticides, which may contribute more than $60 \%$ of registered global bio-fungicides (Abbas et al. 2017). More than 250 bio-fungicides are already registered globally as Trichoderma-formulated products and are considered acceptable worldwide (Kashyap et al. 2017). The sustainable management of plant disease can be achieved using Trichoderma as reported by Al-Ani (2018). 
TABLE 3. List of plant stress controlled by Trichoderma spp. in some cultivatedcrops

\begin{tabular}{|c|c|c|c|}
\hline References & Abiotic and/or biotic stress & Host plant & Trichoderma strain \\
\hline & & & Vegetable crops \\
\hline Khoshmanzar et al. (2020) & $\begin{array}{l}\text { Water-deficit (available water } \\
\text { depletion } 70-90 \% \text { ) }\end{array}$ & Tomato & $\begin{array}{l}\text { T.longibrachiatum, } \\
\text { T. harzianum }\end{array}$ \\
\hline Kashyap et al. (2020) & $\begin{array}{l}\text { Tomatoroot rot (Rhizoctonia solani) } \\
\text { and } 250 \mathrm{mMNaCl}\end{array}$ & Tomato & $\begin{array}{l}\text { Trichoderma asperellum } \\
\text { F01763 }\end{array}$ \\
\hline Sani et al. (2020) & Reduced NPK doses (by $50 \%$ ) & Tomato & T. harzianum $\mathrm{T} 22$ \\
\hline Ghorbanpour et al. (2018) & Low temperature $\left(8^{\circ} \mathrm{C}\right)$ for 6 days & Tomato & $\begin{array}{l}\text { Trichoderma harzianum } \\
\text { (AK20G) }\end{array}$ \\
\hline Eslahi et al. (2020b) & Pathogen(Rhizoctonia solani) & Common bean & $\begin{array}{l}\text { T. harzianum }(\mathrm{T} 13, \mathrm{~T} 15 \\
\text { and wild-type; } \mathrm{Tw})\end{array}$ \\
\hline Vieira et al. (2018) & Pathogen(Fusarium oxysporum) & Common bean & Trichoderma harzianum \\
\hline Juniors et al. (2020) & $\begin{array}{l}\mathrm{Cu} \text { stress as fungicide and } \mathrm{CuSO}_{4} \text { at } \\
100 \mathrm{mg} \mathrm{L}^{-1} \mathrm{Cu}\end{array}$ & Onion & Trichoderma asperellum \\
\hline Zhang and Zhuang (2020) & $\begin{array}{l}\text { The fungus plant-pathogenic } \\
\text { Rhizoctonia solani }\end{array}$ & Cucumber & T. brevicrassum ТC967 \\
\hline Zhang et al. (2019) & $\begin{array}{l}\text { Fusarium oxysporum and irrigated } \\
\text { with } 200 \mathrm{mM} \mathrm{NaCl}\end{array}$ & Cucumber & $\begin{array}{l}\text { Trichoderma harzianum } \\
\text { KC753767 }\end{array}$ \\
\hline Yuan et al. (2019) & $\begin{array}{l}\text { Graymold in cucumber caused by } \\
\text { Botrytis cinerea }\end{array}$ & Cucumber & $\begin{array}{l}\text { T. longibrachiatum } \mathrm{H} 9 \\
\text { Field crops }\end{array}$ \\
\hline Mishra et al. (2020) & $\begin{array}{l}\text { Droughtand sheath blight (Rhizoctonia } \\
\text { solani) }\end{array}$ & Rice & Trichoderma spp. \\
\hline Mishra et al. (2019) & ElevatedCO $\mathrm{C}_{2}(550 \mathrm{ppm})$ & Rice & T. reesei, MTCC5659 \\
\hline Karuppiah et al. (2020) & $\begin{array}{l}\text { Wheatrot disease caused by Fusarium } \\
\text { graminearum }\end{array}$ & Wheat & $\begin{array}{l}\text { Trichoderma atroviride } \\
\mathrm{T} 23\end{array}$ \\
\hline Zhang et al. (2019) & Salinity $\left(10\right.$ and $\left.20 \mathrm{~g} \mathrm{l}^{-1} \mathrm{NaCl}\right)$ & Wheat & $\begin{array}{l}\text { Trichoderma } \\
\text { longibrachiatum }\end{array}$ \\
\hline $\begin{array}{l}\text { Jaroszuk-Dciset et al. } \\
\text { (2019) }\end{array}$ & $\begin{array}{l}\text { Phytopathogen of Fusarium spp. } \\
\text { (F. culmorum, F. oxysporum, } F \text {. } \\
\text { graminearum })\end{array}$ & Wheat & $\begin{array}{l}\text { Trichoderma } \\
\text { DEMTkZ3A0 }\end{array}$ \\
\hline Pehlivan et al. (2021) & $\begin{array}{l}\text { Potentially toxic elements (e.g., As, } \\
\mathrm{Cd}, \mathrm{Cu}, \mathrm{Pb} \text {, and } \mathrm{Zn} \text { ) in soil }(200,500 \\
\left.\text { and } 1000 \mathrm{mg} \mathrm{L}^{-1}\right)\end{array}$ & Maize & $\begin{array}{l}\text { Trichoderma harzianum } \\
\text { TS } 143\end{array}$ \\
\hline $\begin{array}{l}\text { Estévez-Gefriaud et al. } \\
(2020)\end{array}$ & $\begin{array}{l}\text { Drought (under two different water } \\
\text { regimes) }\end{array}$ & Maize & $\begin{array}{l}\text { Trichoderma asperellum } \\
\text { T34 }\end{array}$ \\
\hline Ferrigo et al. (2020) & $\begin{array}{l}\text { Fusarium verticillioides and Fusarium } \\
\text { graminearum }\end{array}$ & Maize & $\begin{array}{l}\text { Trichoderma harzianum } \\
\text { (INAT11) }\end{array}$ \\
\hline Karuppiah et al. (2019) & Fusarium graminearum & Maize & T. asperellum GDFS1009 \\
\hline Fu et al. (2018) & Saline-alkaline soil ( $\mathrm{pH} 9.30)$ & Maize & Trichoderma asperellum \\
\hline Pehlivan et al. (2017) & Salinity (50 and $100 \mathrm{mM} \mathrm{NaCl})$ & Maize & Trichoderma lixii ID11D \\
\hline Prasad et al. (2020) & $\begin{array}{l}\text { Macrophominaphaseolina, Fusarium } \\
\text { oxysporumf. sp.ricini } \\
\text { and Aspergillus niger }\end{array}$ & $\begin{array}{l}\text { Groundnut } \\
\text { and safflower }\end{array}$ & $\begin{array}{l}\text { Trichoderma harzianum } \\
\text { (Th4d) }\end{array}$ \\
\hline de Oliveira et al. (2021) & disease(Pratylenchusbrachyurus) & Soybean & $\begin{array}{l}\text { T.asperellum T00 and } \\
\text { T.harzianum ALL } 42\end{array}$ \\
\hline Mishra andNautiyal(2018) & $\begin{array}{l}\text { Collar rot disease caused by } \\
\text { Sclerotium rolfsii }\end{array}$ & Chickpea & T. viride (MTCC 5661) \\
\hline Tripathi et al. (2017) & $\begin{array}{l}\text { Arsenic stress }\left(100 \mathrm{mg}^{1-} \text { arsenate as }\right. \\
\left.\mathrm{Na}_{2} \mathrm{HAsO}_{4} \cdot 7 \mathrm{H}_{2} \mathrm{O}\right)\end{array}$ & Chickpea & Trichoderma sp. \\
\hline Carro-Huerga et al. (2020) & $\begin{array}{l}\text { Phaeoacremonium minimum CBS } \\
100398 \text { pathogen }\end{array}$ & $\begin{array}{l}\text { Common } \\
\text { grape vine }\end{array}$ & $\begin{array}{l}\text { Viticulturecrops } \\
\text { Trichoderma } \text { sp. strain } \\
\text { T154 }\end{array}$ \\
\hline Marraschi et al. (2019) & Lasiodiplodiatheobromae pathogen & $\begin{array}{l}\text { Common } \\
\text { grape vine }\end{array}$ & $\begin{array}{l}\text { Trichoderma spp. } \\
\text { Forage crops }\end{array}$ \\
\hline Zhang et al. (2020) & $\begin{array}{l}\text { Alkaline-saline soils }(\mathrm{pH}, 8.7 ; \mathrm{EC}=5.4 \\
\left.\mathrm{dS} \mathrm{m}^{-1}\right)\end{array}$ & Alfalfa & T. harzianum NAU14 \\
\hline Anam et al. (2019) & $\begin{array}{l}\text { Sodic-saline-alkali red mud flooded } \\
\text { soil }(\mathrm{pH} 12, \mathrm{NaCl} 4 \%)\end{array}$ & $\begin{array}{l}\text { Sorghum-- } \\
\text { sudangrass }\end{array}$ & $\begin{array}{l}\text { Trichoderma asperellum } \\
\text { RM-28 }\end{array}$ \\
\hline
\end{tabular}




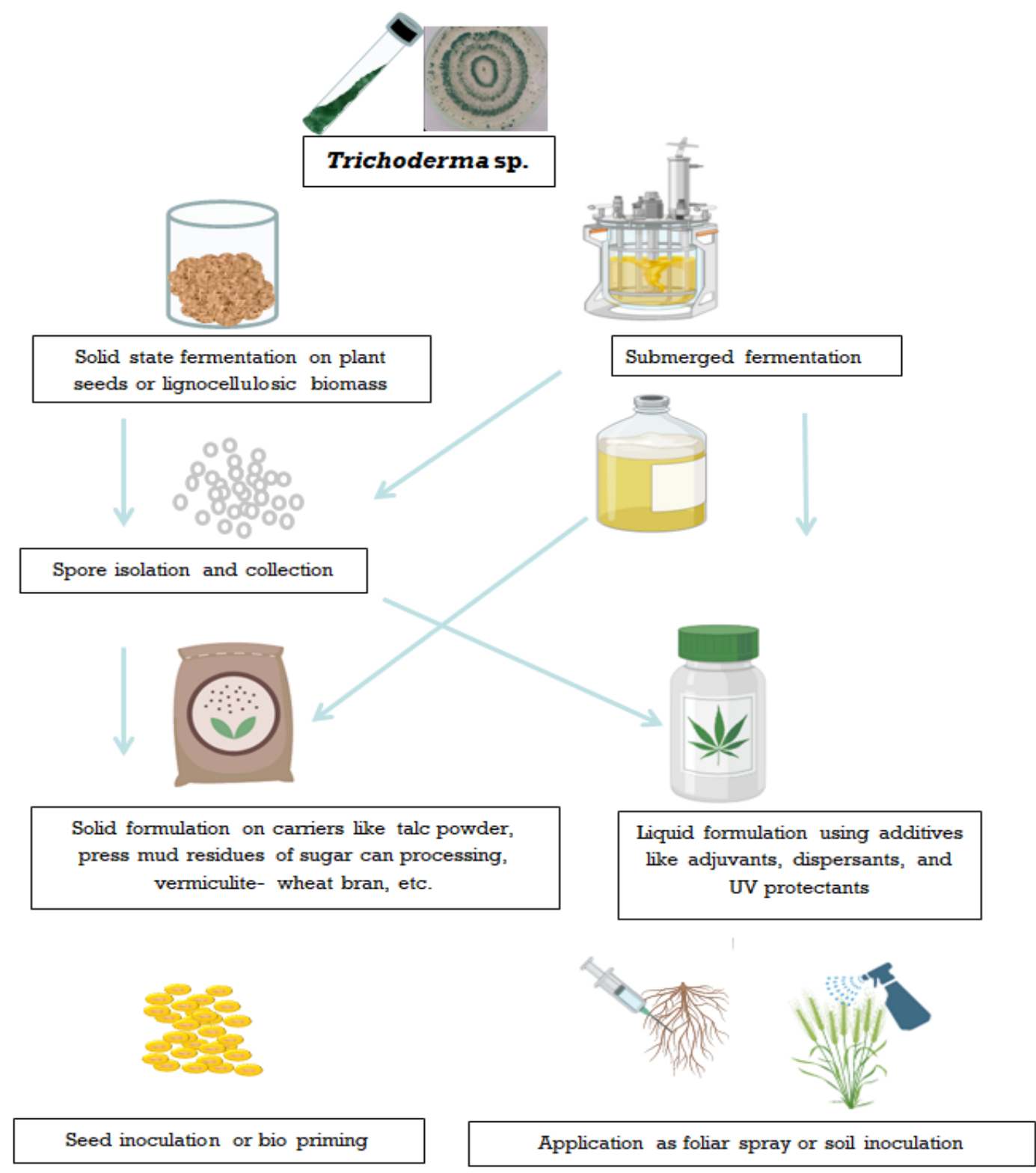

Fig. 6. Schematic diagram for main commercial production methods of Trichoderma sp.

Biofortification of several crops as a sustainable approach could be performed by the application of many beneficial microorganisms (i.e., Trichoderma spp., mycorrhiza fungi and plant growth-promoting rhizobacteria) through enhancing the uptake of nutrients. Therefore, using Trichoderma spp. in crop production could be considered a sustainable and environmentally friendly approach to secure yield stability under low-input conditions (Fiorentino et al. 2018). The biofortification using Trichoderma spp. may increase the plant growth and its development as well the natural antioxidants like total polyphenol and flavonoid and mineral content in cultivated plants (Gorai et al. 2020).

Using the efficiency of rhizospheric bacteria and fungi (Trichoderma sp.) has been utilized for bio-or phyto-remediation purpose. Theremediation of contaminated soils from the toxic heavy metals (e.g., $\mathrm{Cu}, \mathrm{Cd}, \mathrm{Ni}, \mathrm{Pb}$ and $\mathrm{Zn}$ ) or/ and organic pollutants (like pentachlorophenol) could be achieved using many species of Trichoderma due to their effective colonization, capacity of quick asexual reproduction within the rhizospheric and their symbiosis impacts (Gorai 
et al. 2020). It is reported that genus Trichoderma is tolerant to a range of recalcitrant pollutants including pesticides, polyaromatic hydrocarbons and heavy metals. Therefore, Trichoderma sp. can be successfully applied and established as an agent of bio- or phyto-remediation of different environmental pollutants. Some ecological, biochemical, molecular and geneticapproaches should also be integrated for developing of novel technologies (Gorai et al. 2020). Based on the recent studies, many researchers confirmed the role of Trichoderma in the bioremediation of many organic contaminants such asTNT by Trichoderma viride (Alothman et al. 2020), chromium by by Trichoderma viride (ZapanaHuarache et al. 2020), and copper or chromium by Trichoderma lixii CR700 (Kumar and Dwivedi 2019, 2021), diesel byTrichoderma harzianum strain T22 (Elshafie et al. 2020), and polycyclic aromatic hydrocarbons by T. longibrachiatum (Li et al. 2021).

\section{Conclusion}

Trichoderma is an important fungus that live symbiotically with plants.This symbiotic relation has many sustainable benefitsin the agriculture sector. These benefits may include their applications as biofertilizers, biopesticides, biostimulants and soil amendments as well as their roles in biofortification, bioremediation, and phytoremediation. Trichoderma as a biocontrol agent has been widely used against several phytopathogens including bacteria, viruses, nematodes, fungi and higher parasitic plants. Based on their useful mechanisms, Trichoderma might be the best microbe to the plants. These mechanisms may include enhancing the plant growth, producing the secondary metabolites and enzymes, parasitism and antibiosis. The sustainable approaches in using Trichoderma is mainly depend on its useful protection and inhibition a lot of phytopathogens, using as biopesticides, biofertilizers and biostimulants, which save the ecosystem by reducing the residue of chemical synthetic fertilizer and pesticides. The high efficiency of Trichodermaas biostimulants has been approved by modulating the microbial populations in the rhizosphere and by improving $\mathrm{N}$-uptake efficiency, yield and its nutritional quality of some cultivated leafy vegetables.

Ethics approval and consent to participate This article does not contain any studies with human participants or animals performed by any of the authors.

\section{Consent for publication}

All authors declare their consent for publication.

\section{Funding}

This research received no external funding.

\section{Conflicts of Interest}

The author declares no conflict of interest.

\section{Acknowledgments}

The Authors thank the staff members of Physiology and Breeding of Horticultural Crops Laboratory, Dept. of Horticulture, Fac. of Agric., Kafrelsheikh University, Kafr El-Sheikh, Egypt for supporting this work.

\section{References}

Abbas A, Jiang D, Fu Y (2017). Trichoderma spp. as antagonist of Rhizoctonia solani. J Plant Pathol Microbiol. 8: 402. https://doi.org/10.4172/2157$\underline{7471.1000402}$

Abdelrahman M, Abdel-Motaal F, El-Sayed M, Jogaiah S, Shigyo M, Ito S, Tran L-SP (2016). Dissection of Trichoderma longibrachiatum-induced defense in onion (Allium cepa L.) against Fusarium oxysporum f. sp. cepa by target metabolite profiling. Plant Science 246, 128-138.

Al-Ani LKT (2018). Trichoderma: Beneficial Role in Sustainable Agriculture by Plant Disease Management. In: In: Egamberdieva D., Ahmad P. (Eds.) Plant Microbiome: Stress Response. Microorganisms for Sustainability book series (MICRO, vol. 5). pp: 105-126. Springer, Singapore. https://doi.org/10.1007/978-981-10-5514-0_5

Al-Ani LKT, Mohammed AM (2020) Versatility of Trichoderma in plant disease management. In: V. Sharma, R. Salwan and L. K. T. Al-Ani (Eds.), Molecular Aspects of Plant Beneficial Microbes in Agriculture, Academic Press, https://doi. org/10.1016/B978-0-12-818469-1.00013-4, Pp: 159-168.

Alami MM, Xue J, Ma Y, Zhu D, Abbas A, Gong Z, Wang X (2020) Structure, Function, Diversity, and Composition of Fungal Communities in Rhizospheric Soil of Coptis chinensis Franch under a Successive Cropping System. Plants (Basel) 9 (2): 244. doi: 10.3390/plants9020244

Alothman ZA, Bahkali AH, Elgorban AM, AlOtaibiMS, Ghfar AA, Gabr SA, WabaidurSM, 
HabilaMA, Ahmed AYBH (2020). Bioremediation of Explosive TNT by Trichoderma viride. Molecules. 25 (6): 1393. doi: 10.3390/ molecules 25061393

Anam GB, ReddyMS,AhnY-H(2019). Characterization of Trichoderma asperellum RM-28 for its sodic/ saline-alkali tolerance and plant growth promoting activities to alleviate toxicity of red mud. / Science of the Total Environment 662, 462-469. https://doi. org/10.1016/j.scitotenv.2019.01.279

Atieno M, Herrmann 1, Nguyen HT, Phan HT, Nguyen NK, Srean P, Than MM, Zhiyong R, Tittabutr P, Shutsrirung A, Brauh L, Lesueur D (2020). Assessment of biofertilizer use for sustainable agriculture in the Great Mekong Region. Journal of Environmental Management 275,111300. https://doi.org/10.1016/j.jenvman.2020.111300

Bader AN, Salerno GL, Covacevich F, Consolo VF (2020). Native Trichoderma harzianum strains from Argentina produce indole-3 acetic acid and phosphorus solubilization, promote growth and control wilt disease on tomato (Solanum lycopersicum L.). Journal of King Saud University - Science 32, 867-873. https://doi.org/10.1016/j. jksus.2019.04.002

Barros-Rodríguez A, Rangseekaew P, Lasudee K, Pathom-aree W, Manzanera M (2020). Regulatory risks associated with bacteria as biostimulants and biofertilizers in the frame of the European Regulation (EU) 2019/1009. Science of the Total Environment 740, 140239. https://doi. org/10.1016/j.scitotenv.2020.140239

Bayoumi Y, Taha N, Shalaby T, Alshaal T, El-Ramady H (2019). Sulfur promotes biocontrol of purple blotch disease via Trichoderma spp. and enhances the growth, yield and quality of onion. Applied Soil Ecology 134, 15-24. https://doi.org/10.1016/j. apsoil.2018.10.011

Bononi L, Chiaramonte JB, Pansa CC, Alves-Moitinho M, Soares-Melo I (2020) Phosphorus-solubilizing Trichoderma spp. from Amazon soils improve soybean plant growth. Sci. Rep. 10, 2858.

Brotman Y, Lisec J, Méret M, Chet I, Willmitzer L, Viterbo A (2012). Transcript and metabolite analysis of the Trichoderma- induced systemic resistance response to Pseudomonas syringae in Arabidopsis thaliana. Microbiology, 158:139-146.

Bunbury-Blanchette AL, AK Walker (2019). Trichoderma species show biocontrol potential in dual culture and greenhouse bioassays

Env. Biodiv. Soil Security Vol. 4 (2020) against Fusarium basal rot of onion. Biological Control 130, 127-135. https://doi.org/10.1016/j. biocontrol.2018.11.007

Caporale AG, Vitaglione P, Troise AD, Pigna M, Ruocco M (2019) Influence of three different soil types on the interaction of two strains of Trichoderma harzianum with Brassica rapasubsp. sylvestris cv. esculenta, under soil mineral fertilization. Geoderma 350, 11-18. https://doi. org/10.1016/j.geoderma.2019.05.003

Chien Y-C, Huang C-H (2020) Biocontrol of bacterial spot on tomato by foliar spray and growth medium application of Bacillus amyloliquefaciens and Trichoderma asperellum. Eur J Plant Pathol 156: 995-1003. https://doi.org/10.1007/s10658-020$\underline{01947-5}$

Amaresh YS, Chennappa G, Avinash S, Naik MK, Sreenivasa MY (2019) Trichoderma-a new strategy in combating agriculture problems. In: Jay Shankar Singh (Ed.), New and Future Developments in Microbial Biotechnology and Bioengineering: Microbes in Soil, Crop and Environmental Sustainability. DOI: https://doi. org/10.1016/B978-0-12-818258-1.00015-7, pp: 235-244. Elsevier B.V.

Carro-Huerga G, CompantS, GorferM, CardozaRE, SchmollM, GutiérrezS, CasqueroPA (2020) Colonization of Vitis vinifera L. by the Endophyte Trichoderma sp. Strain T154: Biocontrol Activity Against Phaeoacremonium minimum. Front Plant Sci.; 11: 1170. doi: 10.3389/fpls.2020.01170

Cong Y, Fan H, Ma Q, Lu Y, Xu L, Zhang P, Chen K (2019). Mixed culture fermentation between Rhizopus nigricans and Trichoderma pseudokoningii to control cucumber Fusarium wilt. Crop Protection 124, 104857. https://doi. org/10.1016/j.cropro.2019.104857

Coppola M, Cascone P, Di Lelio I, Woo SL, Lorito M, Rao R, Pennacchio F, Guerrieri E, Digilio MC (2019a). Trichoderma atroviride P1 colonization of tomato plants enhances both direct and indirect defense barriers against insects. Front. Physiol. 10, 813. https://doi.org/10.3389/fphys.2019.00813

Coppola M, Diretto G, Digilio MC, Woo SL, Giuliano G, Molisso D, Pennacchio F, Lorito M, Rao R (2019b). Transcriptome and metabolome reprogramming in tomato plants by Trichoderma harzianumprimes and enhances defense responses against aphids. Front. Physiol. 10, 745.

Cordier C, Edel-Hermann V, Martin-Laurent F, Blal B, 
Steinberg C, Alabouvette C (2007) SCAR-based real time PCR to identify a biocontrol strain (T1) of Trichoderma atroviride and study its population dynamics in soils. J. Microbiol. Meth 68, 60-68.

Cucu MA, Gilardi G, Pugliese M, Gullino ML, Garibaldi A (2020) An assessment of the modulation of the population dynamics of pathogenic Fusarium oxysporum f. sp. lycopersici in the tomato rhizosphere by means of the application of Bacillus subtilis QST 713, Trichoderma sp. TW2 and two composts. Biological Control 142, 104158. https:// doi.org/10.1016/j.biocontrol.2019.104158

da Silva LR, Valadares-Inglis MC, Moraes MCB, Magalhães DM, Sifuentes DN, Martins I, de Mello $\operatorname{SCM}(2020)$. Morphological and protein alterations in Sclerotinia sclerotiorum (Lib.) de Bary after exposure to volatile organic compounds of Trichoderma spp. Biological Control 147, 104279. https://doi.org/10.1016/j.biocontrol.2020.104279

de MedeirosHA, Jerônimo Vieira de Araújo Filho, Leandro Grassi de Freitas, Pablo Castillo, María Belén Rubio, Rosa Hermosa, Enrique Monte (2017). Tomato progeny inherit resistance to the nematode Meloidogyne javanica linked to plant growth induced by the biocontrol fungus Trichoderma atroviride. Sci Rep. 7: 40216. doi: 10.1038/srep40216

De Palma M, Salzano M, VillanoC, AversanoR, LoritoM, RuoccoM, DocimoT, PiccinelliAL, D'AgostinoN, Tucci M (2019) Transcriptome reprogramming, epigenetic modifications and alternative splicing orchestrate the tomato root response to the beneficial fungus Trichoderma harzianum. Hortic Res. 6: 5. doi: 10.1038/s41438018-0079-1

de Oliveira CM, Almeida NO, Côrtes MVCB, Júnior ML, da Rocha MR, Ulhoa CJ (2021) Biological control of Pratylenchusbrachyurus with isolates of Trichoderma spp. on soybean. Biological Control 152, 104425. https://doi.org/10.1016/j. biocontrol.2020.104425

Doni F, Zain CRCM, Isahak A, Fathurrahman F, Anhar A, Mohamad WNW, Yusoff WMW, Uphoff N (2018). A simple, efficient, and farmer-friendly Trichoderma-based biofertilizer evaluated with the SRI Rice Management System. Org. Agr. 8: 207223. DOI 10.1007/s13165-017-0185-7

dos Santos Pereira T, Macêdo AG, da Silva J, Pinheiro JB, de Paula AM, Biscaia D, Busato JG (2020) Water-extractable fraction of vermicomposts enriched with Trichoderma enhances the growth of bell pepper and tomato as well as their tolerance against Meloidogyne incognita. Scientia Horticulturae 272, 109536. https://doi. org/10.1016/j.scienta.2020.109536

Elazouni I, Abdel-Aziz S, Rabea A (2019) Microbial efficacy as biological agents for potato enrichment as well as bio-controls against wilt disease caused by Ralstonia solanacearum. World Journal of Microbiology and Biotechnology, 35:30 https:// doi.org/10.1007/s11274-019-2596-y

EbertAW (2020). The Role of Vegetable Genetic Resources in Nutrition Security and Vegetable Breeding. Plants (Basel) 9 (6): 736. doi: 10.3390/ plants9060736

El Enshasy HA, Ambehabati KK, El Baz AF, Ramchuran S, Sayyed RZ, Amalin D, Dailin DJ, HanapiSZ (2020) Trichoderma: Biocontrol Agents for Promoting Plant Growth and Soil Health. In: A. N. Yadav et al. (Eds.), Agriculturally Important Fungi for Sustainable Agriculture, Fungal Biology, https://doi.org/10.1007/978-3-030-48474-3_8, pp:239 - 259. Springer Nature Switzerland AG

El-GhamryAM, Mosa AA, Alshaal TA, El-Ramady HR (2018). Nanofertilizers vs. biofertilizers: new insights. Environ. Biodiv. Soil Security, 2, 1-22. https://doi.org/10. 21608/jenvbs.2018.3880.1029.

Elshahawy IE, El-Mohamedy RS (2019). Biological control of Pythium damping-off and root-rot diseases of tomato using Trichoderma isolates employed alone or in combination. Journal of Plant Pathology 101:597-608. https://doi.org/10.1007/ $\underline{\mathrm{s} 42161-019-00248-\mathrm{Z}}$

ElshafieHS, Camele I, Sofo A, Mazzone G, Caivano M, MasiS, Caniani D (2020). Mycoremediation effect of Trichoderma harzianum strain T22 combined with ozonation in diesel-contaminated sand. Chemosphere 252, 126597. https://doi. org/10.1016/j.chemosphere.2020.126597

Eslahi N, Kowsari M, Zamani MR, Motallebi M (2020b). The profile change of defense pathways in phaseouls vulgaris L. by biochemical and molecular interactions of Trichoderma harzianum transformants overexpressing a chimeric chitinase. Biological Control, 104304, https://doi. org/10.1016/j.biocontrol.2020.104304

Eslahi N, Kowsari M, Motallebi M, Zamani MR, Moghadasi Z (2020a) Influence of recombinant Trichoderma strains on growth of bean (Phaseolus vulgaris L) by increased root colonization Env. Biodiv. Soil Security Vol. 4 (2020) 
and induction of root growth related genes. Scientia Horticulturae 261, 108932. https://doi. org/10.1016/j.scienta.2019.108932

Estévez-Gefriaud V, Vicente R, Vergara-DíazO, ReinaldoJJN, TrillasMI (2020). Application of Trichoderma asperellum T34 on maize (Zea mays) seeds protects against drought stress. Planta 252:8 https://doi.org/10.1007/s00425-020-03404-3

Fiorentino N, Ventorino V, WooSL, PepeO, De RosaA, GioiaL, RomanoI, LombardiN, NapolitanoM, CollaG, RouphaelY (2018). TrichodermaBased Biostimulants Modulate Rhizosphere Microbial Populations and Improve N Uptake Efficiency, Yield and Nutritional Quality of Leafy Vegetables. Front Plant Sci. 9: 743. doi: 10.3389/ fpls.2018.00743

Ferrigo D, Mondin M, Ladurner E, Fiorentini F, Causin R, Raiola A (2020). Effect of seed biopriming with Trichoderma harzianum strain INAT11 on Fusarium ear rot and Gibberella ear rot diseases. Biological Control, 147, 104286. https://doi. org/10.1016/j.biocontrol.2020.104286

Fu J, Wang Y, Liu Z, LiZ, YangK (2018). Trichoderma asperellum alleviates the effects of saline-alkaline stress on maize seedlings via the regulation of photosynthesis and nitrogen metabolism. Plant Growth Regulation, 85: 363-374. https://doi. org/10.1007/s10725-018-0386-4

González-Pérez E, Ortega-Amaro MA, SalazarBadillo FB, Bautista E, Douterlungne D, JiménezBremont JF (2018). The Arabidopsis-Trichoderma interaction reveals that the fungal growth medium is an important factor in plant growth induction. Sci. Rep. 8, 16427.

Gorai PS, Barman S, Gond SK, MandalNC (2020). Trichoderma. In: N. Amaresan et al. (Eds.), Beneficial Microbes in Agro-Ecology. https:// doi.org/10.1016/B978-0-12-823414-3.00028-9, Elsevier Inc.

Ghorbanpour A, Salimi A, Ghanbary MAT, PirdashtiH, DehestaniA (2018) The effect of Trichoderma harzianum in mitigating low temperature stress in tomato (Solanum lycopersicum L.) plants. Scientia Horticulturae, 230, 134-141.

Gautam RL, Naraian R (2020). Trichoderma, a Factory of Multipurpose Enzymes: Cloning of Enzymatic Genes. In: A. E.-L Hesham et al. (Eds.), Fungal Biotechnology and Bioengineering, Fungal Biology, https://doi.org/10.1007/978-3030-41870-0_5, pp: 137 - 162. Springer Nature

Env. Biodiv. Soil Security Vol. 4 (2020)

\section{Switzerland AG}

Herrera-Téllez VI, Cruz-Olmedo AK, Plasencia J, Gavilanes-Ruíz M, Arce-Cervantes O, HernándezLeón S, Saucedo-García M (2019) The Protective Effect of Trichoderma asperellum on Tomato Plants against Fusarium oxysporum and Botrytis cinerea Diseases Involves Inhibition of Reactive Oxygen Species Production. Int J Mol Sci. 20 (8): 2007. doi: 10.3390/ijms20082007

Jaroszuk-Ściseł J, Tyśkiewicz R, Nowak A, Ozimek E, Majewska M, Hanaka A, Tyロkiewicz K, Pawlik A, Janusz G (2019) Phytohormones (Auxin, Gibberellin) and ACC Deaminase In Vitro Synthesized by the MycoparasiticTrichoderma DEMTkZ3A0 Strain and Changes in the Level of Auxin and Plant Resistance Markers in Wheat Seedlings Inoculated with this Strain Conidia. Int $J$ Mol Sci. 20 (19): 4923. doi: 10.3390/ijms20194923

Ji S, Liu Z, Bin Liu, Wang Y, Wang J (2020) The effect of Trichoderma biofertilizer on the quality of flowering Chinese cabbage and the soil environment. Scientia Horticulturae, 26227, 109069. https://doi.org/10.1016/j. scienta.2019.109069

Jogaiah S, Abdelrahman M, Tran L-SP, S-I Ito (2018) Different mechanisms of Trichoderma virensmediated resistance in tomato against Fusarium wilt involve the jasmonic and salicylic acid pathways. Mol Plant Pathol. 19 (4): 870-882. doi: 10.1111/mpp. 12571

Juniors P-TE, ValeriaC-L, Santiago P-O, Mario R-M, Gabriela S-J (2020) Tolerance to oxidative stress caused by copper $(\mathrm{Cu})$ in Trichoderma asperellum To. Biocatalysis and Agricultural Biotechnology, 29, 101783, https://doi.org/10.1016/j. bcab.2020.101783

Karuppiah V, Li Y, Sun J, Vallikkannu M, ChenJ (2020). Vell regulates the growth of Trichoderma atroviride during co-cultivation with Bacillus amyloliquefaciens and is essential for wheat root rot control. Biological Control, 151, 104374. https://doi.org/10.1016/j.biocontrol.2020.104374

Karuppiah V, Vallikkannu M, Li T, Chen J (2019). Simultaneous and sequential based co-fermentations of Trichoderma asperellum GDFS1009 and Bacillus amyloliquefaciens 1841: a strategy to enhance the gene expression and metabolites to improve thebiocontrol andplant growth promoting activity. Microb Cell Fact, 18:185 https://doi.org/10.1186/s12934019-1233-7 
Kashyap PL, Solanki MK, Kushwaha P, Kumar S, Srivastava AK (2020). Biocontrol Potential of SaltTolerant Trichoderma and Hypocrea Isolates for the Management of Tomato Root Rot Under Saline Environment. Journal of Soil Science and Plant Nutrition, 20:160-176. https://doi.org/10.1007/ s42729-019-00114-y

Kashyap PL, Rai P, Srivastava AK, Kumar S (2017). Trichoderma for climate resilient agriculture. World J Microbiol Biotechnol. 33 (8):155. https:// doi.org/10.1007/s11274-017-2319-1

Khan MY, Haque MM, Molla AH, Rahman MM, Alam MZ (2017). Antioxidant compounds and minerals in tomatoes by Trichodermaenriched biofertilizer and their relationship with the soil environments Journal of Integrative Agriculture, 16 (3): 691703. doi: 10.1016/S2095-3119(16)61350-3

Khare E, Tyagi S, Patil KS (2020). Language of plantmicrobe-microbe interactions in rhizospheric ecosystems. In: Vivek Sharma et al. (Eds.), Molecular Aspects of Plant Beneficial Microbes in Agriculture. DOI: https://doi.org/10.1016/B978-012-818469-1.00005-5, pp: 59 - 76. Elsevier Inc.

Konappa N, Krishnamurthy S, Siddaiah NC, Ramachandrappa NS, Chowdappa S (2018). Evaluation of biological efficacy of Trichoderma asperellum against tomato bacterial wilt caused by Ralstonia solanacearum. Egypt. J. Biol. Pest Control, 28, 63.

Khoshmanzar E, Aliasgharzad N, Neyshabouri MR, Khoshru B, Arzanlou M, Lajayer BA (2020). Effects of Trichoderma isolates on tomato growth and inducing its tolerance to water-deficit stress. International Journal of Environmental Science and Technology, 17:869-878 https://doi. org/10.1007/s13762-019-02405-4

Konappa N, Krishnamurthy S, Arakere UC, Chowdappa S, Ramachandrappa NS (2020) Efficacy of indigenous plant growth promoting rhizobacteria and Trichoderma strains in eliciting resistance against bacterial wilt in a tomato. Egyptian Journal of Biological Pest Control, 30:106. https://doi. org/10.1186/s41938-020-00303-3

Kredics L, Chen L, Kedves O, Büchner R, Hatvani L, Allaga H, Nagy VD, Khaled JM, Alharbi NS, Vágvölgyi C (2018) Molecular Tools for Monitoring Trichoderma in Agricultural Environments. Front Microbiol. 9: 1599. doi: 10.3389/fmicb.2018.01599
Kubicek CP, Steindorff AS, Chenthamara K, Manganiello G, Henrissat B, Zhang J, Cai F, Kopchinskiy AG, Kubicek EM, Kuo A, Baroncelli R, Sarrocco S, Noronha EF, Vannacci G, Shen Q, Grigoriev IV, Druzhinina IS (2019) Evolution and comparative genomics of the most common Trichoderma species. BMC Genomics. 20: 485. doi: $10.1186 / \mathrm{s} 12864-019-5680-7$

Kumari R, Singh DP (2019). Nano-biofertilizer: An Emerging Eco-friendly Approach for Sustainable Agriculture. Proc. Natl. Acad. Sci., India, Sect. B Biol. Sci. https://doi.org/10.1007/s40011-019$\underline{01133-6}$

Kumar V, Dwivedi SK (2021) Bioremediation mechanism and potential of copper by actively growing fungus Trichoderma lixii CR700 isolated from electroplating wastewater. Journal of Environmental Management, 277, 111370. https:// doi.org/10.1016/j.jenvman.2020.111370

Kumar V, Dwivedi SK (2019). Hexavalent chromium stress response, reduction capability and bioremediation potential of Trichoderma sp. isolated from electroplating wastewater. Ecotoxicology and Environmental Safety, 185, 109734. https://doi.org/10.1016/j. ecoenv.2019.109734

Kumari I, Sharma S, Geetika, Ahmed M (2020). Tripartite interactions between plants, trichoderma and the pathogenic fungi. In: V. Sharma, R. Salwan and L. K. T. Al-Ani (Eds.), Molecular Aspects of Plant Beneficial Microbes in Agriculture, Academic Press, https://doi.org/10.1016/B978-012-818469-1.00032-, Pp: 391-401.

Li M, Ma G, Lian H, Su X, Tian Y, Huang W, Mei J, Jiang X (2019). The effects of Trichoderma on preventing cucumber fusarium wilt and regulating cucumber physiology. Journal of Integrative Agriculture, 18 (3): 607-617. doi: 10.1016/S20953119(18)62057-X

Li Q, Li J, Jiang L, Sun Y, Luo C, Zhang G (2021). Diversity and structure of phenanthrene degrading bacterial communities associated with fungal bioremediation in petroleum contaminated soil. Journal of Hazardous Materials, 403, 123895. https://doi.org/10.1016/j.jhazmat.2020.123895

Li Y-T, Hwang S-G, Huang Y-M, Huang C-H (2018) Effects of Trichoderma asperellum on nutrient uptake and Fusarium wilt of tomato. Crop Protection, 110, 275-282. http://dx.doi. 
$\underline{\text { org/10.1016/j.cropro.2017.03.021 }}$

Liu S-Y, Liao C-K, Lo C-T, Yang H-H, Lin K-C, Peng K-C (2016). Chrysophanol is involved in the biofertilization and biocontrol activities of Trichoderma. Physiological and Molecular Plant Pathology 96, 1-7. http://dx.doi.org/10.1016/j. pmpp.2016.06.003

Macías-Rodríguez L, Contreras-Cornejo HA, Adame-Garnica SG, del-Val E, Larsen J (2020). The interactions of Trichoderma at multiple trophic levels: inter-kingdom communication. Microbiological Research, 126552. doi:10.1016/j. micres.2020.126552

Mącik M, Gryta A, Frąc M (2020) Biofertilizers in agriculture: An overview on concepts, strategies and effects on soil microorganisms. In: Donald L. Sparks (Ed.), Advances in Agronomy, Volume 162, pp: 31 -87. Elsevier Inc. ISSN 0065-2113 All rights reserved. https://doi.org/10.1016/ bs.agron.2020.02.001

Marraschi R, FerreiraABM, da Silva BuenoRN, LeiteJABP, LuconCMM, HarakavaR, LeiteLG, PadovaniCR, Bueno CJ (2019) A protocol for selection of Trichoderma spp. to protect grapevine pruning wounds against Lasiodiplodia theobromae. Braz J Microbiol. 50 (1): 213-221. doi: 10.1007/s42770-018-0029-y

Malinich EA, Wang K, Mukherjee PK, Kolomiets M, Kenerley CM (2019) Differential expression analysis of Trichoderma virens RNA reveals a dynamic transcriptome during colonization of Zea mays roots. BMC Genomics, 20 (1): 280. https:// doi.org/10.1186/s12864-019-5651-z

Mishra D, RajputRS, Zaidi NW, SinghHB (2020). Sheath blight and drought stress management in rice (Oryza sativa) through Trichoderma spp. Indian Phytopathology, 73: 71-77. https://doi. org/10.1007/s42360-019-00189-8

Mishra A, Singh SP, Mahfooz S, Shukla R, Mishra N, Pandey S, Dwivedi S, Pandey V, Shirke PA, Nautiya CS (2019). External Supplement of Impulsive Micromanager Trichoderma Helps in Combating $\mathrm{CO}_{2}$ Stress in Rice Grown Under FACE. Plant Molecular Biology Reporter, 37:1-13 https://doi.org/10.1007/s11105-018-1133-8

Mishra A, Nautiyal CS (2018). A novel Trichoderma fusant for enhancing nutritional value and defence activity in chickpea. Physiol Mol Biol Plants, 24 (3): 411-422 https://doi.org/10.1007/s12298-017$\underline{0500-5}$

Env. Biodiv. Soil Security Vol. 4 (2020)
Mohamed BFF, Sallam NMA, Alamri SAM, AboElyousr KAM, Mostafa YS, Hashem M (2020) Approving the biocontrol method of potato wilt caused by Ralstonia solanacearum (Smith) using Enterobacter cloacae PS14 and Trichoderma asperellum T34. Egyptian Journal of Biological Pest Control, 30: 61. https://doi.org/10.1186/ $\underline{\mathrm{s} 41938-020-00262-9}$

Morán-Diez ME, Tranque E, Bettiol W, Monte E, Hermosa R (2020). Differential Response of Tomato Plants to the Application of Three Trichoderma Species When Evaluating the Control of Pseudomonas syringae Populations. Plants (Basel) 9 (5): 626. doi: 10.3390/plants9050626

Nawrocka J, GromekA, Małolepsza U (2019). Nitric Oxide as a Beneficial Signaling Molecule in Trichoderma atroviride TRS25-Induced Systemic Defense Responses of Cucumber Plants Against Rhizoctonia solani. Front Plant Sci. 10: 421. doi: 10.3389/fpls.2019.00421

Nawrocka J, Małolepsza U, Szymczak K, Szczech M (2018). Involvement of metabolic components, volatile compounds, PR proteins, and mechanical strengthening in multilayer protection of cucumber plants against Rhizoctonia solani activated by Trichoderma atroviride TRS25. Protoplasma 255: 359-373. DOI 10.1007/s00709-017-1157-1

Pehlivan N, Yesilyurt AM, Durmus N, Karaoglu SA (2017). Trichoderma lixii ID11D seed biopriming mitigates dose dependent salt toxicity in maize. Acta Physiol Plant, 39: 79. DOI 10.1007/s11738017-2375-z

Pehlivan N, Gedik K, Eltem R, Terzi E (2021) Dynamic interactions of Trichoderma harzianum TS 143 from an old mining site in Turkey for potent metal(oid)s phytoextraction and bioenergy crop farming. Journal of Hazardous Materials, 403, 123609. https://doi.org/10.1016/j. jhazmat.2020.123609

Persoon CH (1794). Disposita methodical fungorum. Romers. Neues. Mag. Bot. 1, 81-128.

Poveda J, Eugui D, Abril-Urias P (2020) Could Trichoderma Be a Plant Pathogen? Successful Root Colonization. In: A. K. Sharma, P. Sharma (Eds.), Trichoderma, Rhizosphere Biology, https:// doi.org/10.1007/978-981-15-3321-1_3, pp: 35 59. Springer Nature Singapore Pte Ltd.

Prasad RD, Chandrika KSV, Godbole V (2020) A novel chitosan biopolymer based Trichoderma delivery system: Storage stability, persistence 
and bio efficacy against seed and soil borne diseases of oilseed crops. Microbiological Research, 237, 126487. https://doi.org/10.1016/j. micres.2020.126487

Qiao M, Du X, Zhang Z, Xu JP, Yu ZF (2018) Three new species of soil-inhabiting Trichoderma from southwest China. MycoKeys, 44, 63-80.

Ramírez-Cariño HF, Guadarrama-Mendoza PC, Sanchez-Lopez V, Cuervo-Parra JA, RamırezReyes T, Dunlap CA, Valadez-Blanco R (2020) Biocontrol of Alternaria alternata and Fusarium oxysporum by Trichoderma asperelloides and Bacillus paralicheniformis in tomato plants. Antonie van Leeuwenhoek, 113: 1247-1261. https://doi.org/10.1007/s10482-020-01433-2

Rivera-Méndez W (2020). Trichoderma Interactions in Vegetable Rhizosphere Under Tropical Weather Conditions. In: A. K. Sharma, P. Sharma (Eds.), Trichoderma, Rhizosphere Biology, https://doi. org/10.1007/978-981-15-3321-1_15, pp: 293 314. Springer Nature Singapore Pte Ltd.

Rivera-Méndez W, Miguel Obregónc, María E. MoránDiezb , Rosa Hermosab , Enrique Monte (2020) Trichoderma asperellum biocontrol activity and induction of systemic defenses against Sclerotium cepivorum in onion plants under tropical climate conditions. Biological Control, 141, 104145. https://doi.org/10.1016/j.biocontrol.2019.104145

Rebolledo-Prudencioa OG, Dautt-Castroa M, EstradaRivera M, González-López MC, Jijón-Moreno S, Casas-Flores S (2020) Trichoderma in the rhizosphere: an approach toward a long and successful symbiosis with plants. In: Vijai Kumar Gupta et al. (Eds.), New and Future Developments in Microbial Biotechnology and Bioengineering: Recent Developments in Trichoderma Research, pp. 3 - 38. https://doi.org/10.1016/B978-0-12819453-9.00001-5, Elsevier B.V.

Sachdev S, Singh A, Singh RP (2018) Optimization of culture conditions for mass production and bioformulation of Trichoderma using response surface methodology. 3 Biotech. 8 (8):360

Sachdev S, Singh RP(2018). Isolation, characterization and screening of native microbial isolates for biocontrol of fungal pathogens of tomato. Clim Change Environ Sustain. 6 (1):46-58.

Sachdev S, Singh RP (2020) Trichoderma: A Multifaceted Fungus for Sustainable Agriculture. In: K. Bauddh et al. (Eds.), Ecological and Practical Applications for Sustainable Agriculture, https:// doi.org/10.1007/978-981-15-3372-3_13,pp: 261 304. Springer Nature Singapore Pte Ltd.

Sahu PK, Gupta A, Singh M,Mehrotra P, BrahmaprakashGP (2018) Bioformulation and Fluid Bed Drying: A New Approach Towards an Improved BiofertilizerFormulation. In: R. S. Sengar, A. Singh (Eds.), Eco-friendly Agrobiological Techniques for Enhancing Crop Productivity, https://doi.org/10.1007/978-981-106934-5_3 , pp: 47 - 62. Springer Nature Singapore Pte Ltd.

Salas-Marina MA, Silva-Flores MA, Uresti-Rivera EE, Castro-Longoria E, Herrera-Estrella A, CasasFlores S (2011) Colonization of Arabidopsis roots by Trichoderma atroviride promotes growth and enhances systemic disease resistance through jasmonic acid/ethylene and salicylic acid pathways. Eur J Plant Pathol. 131:15-26.

SallamNMA, Eraky AMI, Sallam A (2019) Effect of Trichoderma spp. on Fusarium wilt disease of tomato. Molecular Biology Reports, 46: 44634470. https://doi.org/10.1007/s11033-019-04901-9

Sani MNH, Hasan M, Uddain J, Subramaniam S (2020) Impact of application of Trichoderma and biochar on growth, productivity and nutritional quality of tomato under reduced N-P-K fertilization. Annals of Agricultural Sciences, 65, 107-115. https://doi. org/10.1016/j.aoas.2020.06.003

Saravanakumar K, Wang M-H (2020). Isolation and molecular identification of Trichoderma species from wetland soil and their antagonistic activity against phytopathogens. Physiological and Molecular Plant Pathology, 109, 101458. https:// doi.org/10.1016/j.pmpp.2020.101458

Singh P, Singh J, Ray S, Rajput RS, Vaishnav A, Singh RK, Singh HB (2020) Seed biopriming with antagonistic microbes and ascorbic acid induce resistance in tomato against Fusarium wilt. Microbiological Research, 237, 126482. https:// doi.org/10.1016/j.micres.2020.126482

Singh SP, Pandey S, Mishra N, Giri VP, Mahfooz S, Bhattacharya A, Kumari M, Chauhan P, Verma P, Nautiyal CS, Mishra A (2019) Supplementation of Trichoderma improves the alteration of nutrient allocation and transporter genes expression in rice under nutrient deficiencies. Plant Physiology and Biochemistry, 143, 351-363. https://doi. org/10.1016/j.plaphy.2019.09.015

Sohrabi F, Sheikholeslami M, Heydari R, Rezaee S, Sharif R (2020) Investigating the effect 
of Glomus mosseae, Bacillus subtilisand Trichoderma harzianum on plant growth and controllingMeloidogyne javanica in tomato. Indian Phytopathology, 73: 293-300. https://doi. org/10.1007/s42360-020-00227-w

Solanki MK, Kashyap PL, Ansari RA, Kumari B (2021) Microbiomes and Plant Health: Panoply and Their Applications. https://doi.org/10.1016/ C2019-0-00466-9Elsevier Inc.

Sood M, Kapoor D, Kumar V, SheteiwyMS, RamakrishnanM, LandiM, AranitiF, SharmaA (2020). Trichoderma: The "Secrets" of a Multitalented Biocontrol Agent. Plants (Basel) 9 (6): 762. doi: 10.3390/plants9060762

Suárez-Estrella F, Ros M, Vargas-García MC, López MJ, Moreno J (2014) Control of Xanthomonas campestrispv. vesicatoria using agroindustrial wasted-based compost. J. Plant Pathol. 96 (2):243-248.

Swain H, Adak T, Mukherjee AK, Mukherjee PK, Bhattacharyya P, Behera S, Bagchi TB, Patro R, Shasmita, Khandual A, Bag MK, Dangar TK, Lenka S, Jena M (2018) Novel Trichoderma strains isolated from tree barks as potential biocontrol agents and biofertilizers for direct seeded rice. Microbiological Research, 214, 83-90. https://doi. org/10.1016/j.micres.2018.05.015

Thakur M (2020). Fungi as a Biological Tool for Sustainable Agriculture. In: A. N. Yadav et al. (Eds.) Agriculturally Important Fungi for Sustainable Agriculture, Fungal Biology, https:// doi.org/10.1007/978-3-030-45971-0_11, Springer Nature Switzerland AG, pp: 255 - 273.

TripathiAN, MeenaBR, PandeyKK, Singh J (2020) Microbial Bioagents in Agriculture: Current Status and Prospects. In: A. Rakshit et al. (Eds.), New Frontiers in Stress Management for Durable Agriculture, https://doi.org/10.1007/978-981-151322-0_20,Springer Nature Singapore Pte Ltd. Pp: $331-368$.

Tripathi P, Singh PC, Mishra A, Srivastava S, Chauhan R, Awasthi S, Mishra S, Dwivedi S, Tripathi P, Kalra A, Tripathi RD, Nautiyal CS (2017) Arsenic tolerant Trichoderma $s p$. reduces arsenic induced stress in chickpea (Cicer arietinum) Environ Pollut. 223:137-145. https://doi.org/10.1016/j. envpol.2016.12.073

Umadevi P, Anandaraj M, Srivastav V, Benjamin S (2018) Trichoderma harzianum MTCC 5179 impacts the population and functional dynamics of microbial community in the rhizosphere of black pepper (Piper nigrum L.). Brazilian Journal of Microbiology, 49, 463-470.https://doi. org/10.1016/j.bjm.2017.05.011

Vieira PM, Zeilinger S, Brandão RS, Vianna GR, Ulhoa CJ (2018) Overexpression of an aquaglyceroporin gene in Trichoderma harzianum affects stress tolerance, pathogen antagonism and Phaseolus vulgaris development. Biological Control 126, 185-191.

Wang X, Xu S, Wu S, Feng S, Bai Z, Zhuang G, Zhuang X (2018) Effect of Trichoderma viride biofertilizer on ammonia volatilization from an alkaline soil in Northern China. Journal of Environmental Sciences, 66, 199 - 207. http:// dx.doi.org/10.1016/j.jes.2017.05.016

Wang Z, LiY, Zhuang L, YuY, Liu J, Zhang L, Gao Z, WuY, Gao W, Ding G, Wang Q (2019) A Rhizosphere-Derived Consortium of Bacillus subtilis and Trichoderma harzianum Suppresses Common Scab of Potato and Increases Yield. Comput Struct Biotechnol J. 17: 645-653. https:// doi.org/10.1016/j.csbj.2019.05.003

Wonglom P, Ito S, Sunpapao A (2020). Volatile organic compounds emitted from endophytic fungus Trichoderma asperellum $\mathrm{T} 1$ mediate antifungal activity, defense response and promote plant growth in lettuce (Lactuca sativa). Fungal Ecology, 43, 100867. https://doi.org/10.1016/j. funeco.2019.100867

Yin M, FasoyinOE, WangC, YueQ, ZhangY, DunB, XuY, ZhangL (2020). Herbicidal efficacy of harzianumsproduced by the biofertilizer fungus, Trichoderma brevicompactum. AMB Express. 10: 118. doi: 10.1186/s13568-020-01055-x

Yu Z, Wang Z, Zhang Y, Wang Y, Liu Z (2020). Biocontrol and growth-promoting effect of Trichoderma asperellum TaspHul isolate from Juglans mandshurica rhizosphere soil. Microbiological Research, 126596,doi: https://doi. org/10.1016/j.micres.2020.126596

Yuan M, Huang Y, Ge W, Jia Z, Song S, Zhang L, Huang Y (2019) Involvement of jasmonic acid, ethylene and salicylic acid signaling pathways behind the systemic resistance induced by Trichoderma longibrachiatum H9 in cucumber. BMC Genomics, 20: 144. https://doi.org/10.1186/ s12864-019-5513-8

Zapata-Sarmiento DH, Palacios-Pala EF, RodríguezHernández AA, Melchor DLM, Rodríguez-Monroy 
M, Sepúlveda-Jiménez G (2020). Trichoderma asperellum, a potential biological control agent of Stemphylium vesicarium, on onion (Allium cepa L.). Biological Control, 140, 104105. https://doi. org/10.1016/j.biocontrol.2019.104105

Zapana-Huarache SV, Romero-Sánchez CK, DueñasGonza AP, Torres-Huaco FD, Rivera AML (2020). Chromium (VI) bioremediation potential of filamentous fungi isolated from Peruvian tannery industry effluents. Brazilian Journal of Microbiology, 51:271-278.

Zehra A, Meena M, Dubey MK, Aamir M, Upadhyay RS (2017) Synergistic effects of plant defense elicitors and Trichoderma harzianum on enhanced induction of antioxidant defense system in tomato against Fusarium wilt disease. Bot Stud. 58: 44. doi: 10.1186/s40529-017-0198-2

Zhang F, Huo Y, Cobb AB, Luo G, Zhou J, Yang G, Wilson GWT, ZhangY (2018) Trichoderma Biofertilizer Links to Altered Soil Chemistry, Altered Microbial Communities, and Improved Grassland Biomass. Front Microbiol. 9: 848. doi: 10.3389/fmicb.2018.00848

Zhang F, Wang Y, Liu C, Chen F, Ge H, Tian F, Yang T, Ma K, Zhang Y (2019) Trichodermaharzianum mitigates salt stress in cucumber via multiple responses. Ecotoxicol. Environ. Saf. 170, 436-445. https://doi.org/10.1016/j.ecoenv.2018.11.084

Zhang S, Gan Y, Xu B (2019) Mechanisms of the
IAA and ACCdeaminase producing strain of Trichoderma longibrachiatum T6 in enhancing wheat seedling tolerance to $\mathrm{NaCl}$ stress. $B M C$ Plant Biology, 19:22 https://doi.org/10.1186/ $\underline{\text { s12870-018-1618-5 }}$

Zhang Y, Zhuang W-Y (2020). Trichoderma brevicrassum strain TC967 with capacities of diminishing cucumber disease caused by Rhizoctonia solani and promoting plant growth. Biological Control, 142, 104151. https://doi. org/10.1016/j.biocontrol.2019.104151

Zhang F, Huo Y, Cobb AB, Luo G, Zhou J, Yang G, Wilson GWT, Zhang Y (2018). Trichoderma biofertilizer links to altered soil chemistry, altered microbial communities, and improved grassland biomass. Front. Microbiol. 9, 48.

Zhang F, Xu X, Wang G, Wu B, Xiao Y (2020). Medicago sativa and soil microbiome responses to Trichoderma as a biofertilizer in alkaline-saline soils. Applied Soil Ecology, 153, 103573. https:// doi.org/10.1016/j.apsoil.2020.103573

Zhang F, Dou K, Liu C, Chen F, Wu W, Yang T, Li L, Liu T, Yu L (2020) The application potential of Trichoderma T-soybean containing 1- aminocyclopropane-1-carboxylate for maize production. Physiological and Molecular Plant Pathology, 110, 101475. https://doi.org/10.1016/j. pmpp.2020.101475 